WIDER Working Paper 2019/92

Marriage, work, and migration

The role of infrastructure development and gender norms

Amrit Amirapu, ${ }^{1}$ M. Niaz Asadullah, ${ }^{2}$ and Zaki Wahhaj ${ }^{3}$

November 2019 
Abstract: Traditional gender norms can restrict independent migration by women, preventing them from taking advantage of economic opportunities in urban non-agricultural industries. However, women may be able to circumvent such restrictions by using marriage to engage in longdistance migration - if they are wealthy enough to match with the desirable migrating grooms. Guided by a model in which women make marriage and migration decisions jointly, we hypothesize that marriage and labour markets will be inextricably linked by the possibility of marital migration. We use the construction of a major bridge in Bangladesh-which dramatically reduced travel time between the economically deprived north-western region and the industrial belt around Dhaka - as a source of plausibly exogenous variation in migration costs. In accordance with our model's predictions, we find that the bridge construction induced marriage-related migration (not economic migration) among rural women, but only for those women coming from families above a poverty threshold.

Key words: migration, marriage markets, female labour force participation, gender norms

JEL classification: J12, J16, O18, R23

Acknowledgements: We would like to thank participants at the Paris School of Economics Development Seminar, the DIAL (Développement Institutions Mondialisation) Seminar at ParisDauphine University, the SIOE (Society for Institutional and Organizational Economics) Annual Conference in Montreal, the IESR-GLO (Institute for Economic and Social Research and Global Labor Organization) Labor Workshop at Jinan University, China, and the 3rd International Conference on Social Protection at the University of Malaya for their comments and feedback. All remaining errors are our own. This research has been supported by funding through the Australian government's Development Research Awards Scheme (Agreement 66396). The views expressed here are those of the authors and not necessarily those of the Commonwealth of Australia. A version of the paper has also appeared in the working paper series (Studies in Economics 1810) of the University of Kent.

\footnotetext{
${ }^{1}$ School of Economics, University of Kent, Canterbury, United Kingdom; ${ }^{2}$ Faculty of Economics and Administration, University of Malaya, Kuala Lumpur, Malaysia, corresponding author: M.Niaz@um.edu.my; ${ }^{3}$ School of Economics, University of Kent, Canterbury, United Kingdom.
}

This study has been prepared within the UNU-WIDER project Transforming economies—for better jobs

Copyright (C) The Authors 2019

Information and requests: publications@wider.unu.edu

ISSN 1798-7237 ISBN 978-92-9256-728-6

https://doi.org/10.35188/UNU-WIDER/2019/728-6

Typescript prepared by Luke Finley.

The United Nations University World Institute for Development Economics Research provides economic analysis and policy advice with the aim of promoting sustainable and equitable development. The Institute began operations in 1985 in Helsinki, Finland, as the first research and training centre of the United Nations University. Today it is a unique blend of think tank, research institute, and UN agency — providing a range of services from policy advice to governments as well as freely available original research.

The Institute is funded through income from an endowment fund with additional contributions to its work programme from Finland, Sweden, and the United Kingdom as well as earmarked contributions for specific projects from a variety of donors.

Katajanokanlaituri 6 B, 00160 Helsinki, Finland

The views expressed in this paper are those of the author(s), and do not necessarily reflect the views of the Institute or the United Nations University, nor the programme/project donors. 
Large-scale rural-urban migration coupled with a shift in employment from agriculture to manufacturing and services have long been at the heart of development theory (Harris and Todaro 1970; Lewis 1954) and are ubiquitous in countries in the process of economic development. However, most of the past theoretical and empirical work in this area has focused exclusively on understanding the migration and work patterns of men, so that relatively little is known about the potential for and drivers of female migration in a developing economy. In traditional societies, prevailing gender norms can restrict female work participation and independent (i.e. without a family) migration, which suggests that women may be more limited than men in their ability to take advantage of economic opportunities in urban non-agricultural industries. On the other hand, it is well documented that marriage is an important vehicle for female long-distance migration in patrilocal societies (e.g. Rosenzweig and Stark 1989). It is thus possible that marriage may serve as a means by which women can circumvent restrictions on their mobility in order to access economic opportunities in urban areas.

In this paper, we explore these issues using the event of the construction of a major bridge in Bangladesh - which dramatically reduced travel time between the economically deprived northwestern region and the industrial belt located around the capital city Dhaka-as a source of plausibly exogenous variation in migration costs. ${ }^{1}$ Using this natural experiment along with data from a purposely designed nationally representative survey of women covering 20 age cohorts (the 2014 Women's Life Choices and Attitudes Survey or WiLCAS) we estimate the effects of a drop in the cost of migration to the industrial belt on (i) female migration; (ii) marriage patterns; (iii) female labour force participation; and (iv) male and female educational attainment.

We hypothesize that the construction of the bridge-across the Jamuna river-increased the (short-term and long-term) migration of men from north-western Bangladesh towards Dhaka in order to take advantage of the greater economic opportunities there. We develop further hypotheses related to the marriage and migration behaviour of women, guided by a simple theoretical framework. For example, given that marriage is the main vehicle for female migration, we hypothesize that the bridge construction should increase the demand and hence the relative price on the marriage market for those men who are now able to migrate (in comparison with demand for such men prior to the bridge construction). In this scenario, women who are better able to afford the higher price (dowry) of migrating men should match with them and experience higher levels of marriage-related migration towards Dhaka. On the other hand, if marriage is unnecessary for female migration, then the bridge construction would increase female economic migration and labour force participation in the urban sector.

Detailed information on the migration history, employment history, and marriage outcomes of women in the 2014 WiLCAS allow us to test these and other hypotheses with a difference-indifferences methodology. For our identification strategy we rely on the following facts: (i) the bridge reduced travel times to the manufacturing belt around Dhaka for people situated on the western side of the river but not for those situated on the eastern side or in other parts of Bangladesh; (ii) the reduction in travel time varied across locations on the western side of the river, depending on whether accessing the bridge involved a long detour or not; (iii) the practice of early marriage and the absence of a remarriage market meant that later cohorts in our sample could

\footnotetext{
${ }^{1}$ For example, travel time from the city of Bogra in north-western Bangladesh to Dhaka decreased from 12-36 hours to 4 hours (Ahmad et al. 2003) after the bridge opened.
} 
make marriage and other decisions in response to the bridge opening, but earlier cohorts could not. These facts allow us to define as 'treated' all individuals born in regions that benefited greatly from the reduced travel times and in cohorts young enough to have come of marriage age after the construction of the bridge.

Using a linear probability model, we find that women who were exposed to the 'treatment' of sharply reduced migration costs due to the bridge construction experienced a 2.8 percentage point increase in the probability of marrying a groom who migrated to Dhaka. ${ }^{2}$ Hypothesizing that women with richer parents would outbid those with poorer parents in the competition for migrating men, we divide the sample between women whose fathers owned half an acre or more of farmland (a threshold commonly used for poverty-targeted programmes in Bangladesh) and those below the threshold.

We find that women from families above the threshold exposed to the treatment are affected in a range of outcomes, consistent with the hypotheses stated above: they are more likely (by five percentage points) to migrate towards Dhaka, work in the urban manufacturing sector, and pay a higher dowry. There is a statistically significant effect on marriage-related migration (an increase of 3.6 percentage points) but not on economic migration. There is no effect on the probability of a woman matching with a groom born around Dhaka, but there is an increase (of 3.5 percentage points) in the probability that the groom migrates to Dhaka from the other side of the river. By contrast, we find no effects for women whose fathers had less than half an acre of land. We also find that women and men exposed to the treatment obtain more years of schooling and are more likely to attend secondary school.

These empirical findings shed light on both the constraints on and the linkages between the marriage, work, and migration decisions of women in developing countries. In particular, the findings are consistent with the hypothesis that social norms restricting female mobility prevented women from north-western Bangladesh from taking direct advantage of the reduction in migration costs resulting from the bridge construction. Nevertheless, a subset of women were able to migrate to the industrial belt, and thus take up employment in the manufacturing sector, by paying a higher dowry and marrying male migrants from the local marriage market.

The study is closely related to a number of recent papers in the literature. Bryan et al. (2014) use an experimental design to investigate how impoverished households located in the same part of Bangladesh respond to monetary incentives for seasonal migration. Heath and Mushfiq Mobarak (2015) study the growth of female manufacturing jobs around Dhaka and its effect on the marriage, education, and employment outcomes of women situated in nearby villages. Blankespoor et al. (2018) investigate how the Jamuna Bridge affected economic activities in north-western Bangladesh, specifically focusing on population density, economic density, intersectoral labour allocation, and agricultural productivity, using south-western Bangladesh-separated from the country's major growth centres by a different river-as the control group. Unlike our study, these papers do not deal specifically with female long-distance migration. In this respect, our work comes closer to that of Rosenzweig and Stark (1989), who argue, using data from rural India from 197685 , that female marriage-migration decisions formed part of a risk-sharing strategy between bridesending and bride-receiving households. We investigate female marriage-migrations in a more dynamic economy, characterized by rapidly expanding opportunities for female employment in manufacturing and growing integration between the capital and an impoverished region of a developing country.

\footnotetext{
${ }^{2}$ This is a large effect given that the average level of migration in our sample is $4 \%$.
} 
This paper is also related to a wider literature on the economic impact of road and transport infrastructure in developing countries. Recent examples in this literature include Adukia et al. (2017) and Asher and Novosad (2016), who examine the effects of a nationwide road programme in India-connecting villages to the major road network-on educational investments and employment outcomes, respectively. These studies find positive effects on schooling (longer periods of schooling and higher scores) and a shift in household economic activities from agriculture towards wage labour. The sectoral reallocation effect is driven entirely by men, consistent with our hypothesis that social attitudes towards female work may be an important constraint on household responses to new economic opportunities.

Khandker et al. (2009) and Khandker and Koolwal (2011) estimate the effects of a similar road improvement programme in Bangladesh (improving feeder road surfaces, and the construction of culverts, bridges, and drainage structure on rural roads). They find increased school improvement for boys and girls at the secondary level, a reduction in poverty, and wage growth-but the effects are attenuated over time. Unlike our work, these studies do not focus on long-distance migration or deal specifically with female responses to infrastructure development. ${ }^{3}$

The remainder of the paper proceeds as follows. In the following section we provide some background on the context of the study, including basic information on female labour force participation in Bangladesh as well as details regarding the bridge construction-our main source of exogenous variation in migration costs. Next, in Section 3, we describe the data and provide basic descriptive statistics. Before turning to empirics, we sketch a model of marriage and migration in Section 4 that provides a framework within which to interpret the empirical results. With this framework in hand, we describe our empirical methodology (Section 5) followed by our results (Section 6). We conclude with a discussion in Section 7.

\section{Study context}

\subsection{Female work participation}

In the last few decades, the lives of Bangladeshi women have undergone some dramatic changes. Since the 1970s, the fertility rate has seen a sharp drop-from 6.3 in 1975 to 2.3 in 2011 (NIPORT et al. 2013) — commonly attributed to family planning programmes launched in the 1970s (see, for example, Joshi and Schultz 2007). And, since the 1990s, when a number of government-led initiatives were introduced to improve female access to schooling, there have been large increases in female primary and secondary school enrolment (Asadullah and Chaudhury 2009; Schurmann 2009).

The same period saw an expansion in access to credit and increased participation in small enterprises among rural women, alongside the emergence and growth of the export-oriented readymade garments (RMG) sector, which employs large numbers of women. Growing from just 40,000

\footnotetext{
3 A number of recent studies have also looked at the economic effects of major road and rail infrastructure on economic development, including Donaldson and Hornbeck (2016) for the USA; Donaldson (2018) for India; Banerjee et al. (2012) for China; and Bird and Straub (2014) and Morten and Oliveira (2014) for Brazil. However, these studies focus on economic growth, trade flows, and prices, as opposed to household responses via labour choices and migration.

4 These figures refer to the total fertility rate.
} 
workers in 1993, this sector employed about 4 million workers ${ }^{5}$ in 2014,80 per cent of the workforce being female (Khatun et al. 2008). Despite the large numbers of women employed in the RMG sector, female labour force participation in Bangladesh has seen only modest increases in the last three decades. Recent data show female participation in paid work at around 10 per cent (Mahmud and Tasneem 2011). Trends based on Labour Force Survey data indicate that the female participation rate increased from 23.9 per cent in 1990 to 36.0 per cent in 2010 (Rahman and Islam 2013).

The low rate of participation among women is puzzling given the decline in fertility and increase in schooling. One potential barrier is social restriction on the outside movement of women. In their study on the Matlab area using data from the mid-1990s, Anderson and Eswaran (2009) noted that the majority of female respondents had never been to the local market and visited outside of their homes at most once a week. Surveys conducted almost two decades later also confirm considerable restrictions on female mobility outside the home and the persistence of traditional attitudes towards women. Heintz et al. (2018) note that more than 85 per cent of the women in their study either were engaged in a home-based economic activity or were economically inactive, which they attributed to cultural restrictions on women's outside mobility. According to research using WiLCAS 2014 data (the same data used in this study), at least part of the gender gap in paid work participation in rural Bangladesh can be explained by prevailing social norms regarding female mobility (Asadullah and Wahhaj 2017).

\subsection{The Jamuna Multi-Purpose Bridge}

We provide some background information about the Jamuna Multi-Purpose Bridge ${ }^{6}$ in northern Bangladesh, which we use in our analysis as a source of exogenous change in rural-urban migration costs in Bangladesh.

The bridge spans the Jamuna river, one of the three major rivers in Bangladesh, which separates its north-western regions from the rest of the country. The construction of the bridge was the largest ever infrastructure development project to be undertaken in Bangladesh. Construction began in October 1994 and the bridge opened to the public in June 1998. Its opening dramatically reduced journey times between the capital Dhaka and the poorer regions in the north-west. Crossing the river by ferry- the most common mode of transport across the river prior to the opening of the bridge- took more than three hours; while average waiting time for a ferry during periods of heavy traffic, such as the period of the Eid festivities, has been estimated at 36 hours. By contrast, crossing the river using the Jamuna Bridge, including waiting time, takes less than an hour (Blankespoor et al. 2018). According to some estimates, the travel time between Dhaka and the city of Bogra in Rajshahi division declined from 12-36 hours to four hours (Ahmad et al. 2003) following the opening of the bridge.

Some recent studies have attempted to estimate the socioeconomic impact of the bridge. Adopting a difference-in-differences approach using districts immediately adjacent to the bridge, Mahmud and Sawada (2015) estimate that it led to a decrease in household unemployment and a shift from farm to non-farm employment.

Blankespoor et al. (2018) estimate the effects of the bridge on population density, economic density (as measured by nightlight luminosity), intersectoral labour allocation, and agricultural

\footnotetext{
${ }^{5}$ Figures obtained from the Bangladesh Garment Manufacturers and Exporters Association at www.bgmea.com.bd.

${ }^{6}$ While it is commonly referred to as the Jamuna Multi-Purpose Bridge, its official name is Bangabondhu Bridge. In the following, we refer to it simply as the Jamuna Bridge for ease of discussion.
} 
productivity, using a difference-in-differences approach where subdistricts in the Padma region (also separated from Dhaka by a river with no connecting bridge) serve as the control group. They find that, in the long term (beyond seven years after the bridge construction) the Jamuna region experienced an increase in population and economic density, a decline in the labour share of manufacturing, and an increase in the labour share of services. They also find positive effects on agricultural productivity as measured by rice yields.

At the site of the bridge the river flows in a relatively narrow belt, which made it amenable for the construction of the bridge. In particular, it has been argued that the site was chosen for engineering rather than socioeconomic reasons (Mahmud and Sawada 2015). As will be discussed in Section 5 , we use the site of the bridge as a source of exogenous variation in the decline in travel times to Dhaka from the western side of the river, following its opening.

\section{Description of the data and descriptive statistics}

\subsection{Description of the survey}

The analysis in this paper is based on data from the 2014 Women's Life Choices and Attitudes Survey (WiLCAS), a survey of Bangladeshi women purposely designed by the authors for the present study. The survey included individual interviews with a nationally representative sample of women born between 1975 and 1994, and recorded their full migration history from birth onwards. It also includes information on their personal background (place and date of birth, parental characteristics), marital history (including background information on the groom, and premarital transfers), employment (including history of work in the manufacturing sector), and education (enrolment history, highest level of education completed).

The survey was conducted between May and July 2014 based on a sample consisting of (i) all rural households in the 2010 Bangladesh Household Income and Expenditures Survey (HIES) which had at least one female household member in the age group 16-35 years; ${ }^{7}$ and (ii) a stratified sample of urban households based on a full household census in 87 non-metropolitan urban primary sampling units, followed by a random selection of 20 households from each unit. ${ }^{8}$ The 87 primary sampling units were randomly selected from those included in the 2010 HIES, with at least one unit from each district. This procedure yielded a sample of 6,293 individual interviews with women in the age group $20-39$ years (1,557 in urban areas). ${ }^{9}$

\subsection{Descriptive statistics}

Table 1 shows descriptive statistics for the women in our sample. They have a median age of 29 years; the median level of education is five years of schooling; and 94 per cent have experienced marriage, with a median age of first marriage of 16 years. One in four were born in the northwestern regions, separated from Dhaka by the Jamuna river; and 16.9 per cent were born in these

\footnotetext{
${ }^{7}$ About $15 \%$ of the original HIES rural households could not be traced; these were replaced with randomly selected households with comparable demographic characteristics within the same primary sampling unit.

${ }^{8}$ The rationale for conducting a household census in the urban areas to construct a sample rather than revisiting HIES households (as was done in rural areas) was to avoid the risk of high attrition, given that urban households in Bangladesh are typically much more mobile than rural households.

9 The survey also included interviews in households in the 2010 HIES with no women in the targeted age cohorts, and a second phase in which sisters of the original female respondents were traced and interviewed. We do not provide further details about these components of the data as they were not used for the present analysis.
} 
regions and aged 15 or less when the bridge opened in 1998. About 14 per cent presently (i.e. in 2014) live in the industrial belt around Dhaka (specifically the districts of Dhaka, Narayanganj, Tangail, or Gazipur). This may occur if they have a husband who comes from this region (5.5 per cent of the full sample), or if they have a husband who has migrated to this region (4 per cent of the full sample), but also due to economic migration on their own.

Table 1: Summary statistics (for all variables)

\begin{tabular}{|c|c|c|c|c|c|c|}
\hline & count & mean & sd & $\min$ & p50 & $\max$ \\
\hline age & 6,237 & 29.003 & 5.575 & 20 & 29 & 39 \\
\hline education & 6,237 & 5.267 & 3.794 & 0 & 5 & 12 \\
\hline religion of the household & 6,237 & 1.124 & 0.355 & 1 & 1 & 3 \\
\hline father educ & 6,237 & 2.953 & 3.873 & 0 & 0 & 12 \\
\hline mother educ & 6,237 & 1.629 & 2.787 & 0 & 0 & 12 \\
\hline father land & 6,237 & 1.389 & 2.752 & 0 & 1 & 60 \\
\hline father landless & 6,237 & 0.053 & 0.225 & 0 & 0 & 1 \\
\hline father low pay & 6,237 & 0.215 & 0.411 & 0 & 0 & 1 \\
\hline paid work & 6,237 & 0.517 & 0.500 & 0 & 1 & 1 \\
\hline RMG work & 6,237 & 0.053 & 0.223 & 0 & 0 & 1 \\
\hline river cross & 6,237 & 0.795 & 0.404 & 0 & 1 & 1 \\
\hline cross Jamuna & 6,237 & 0.256 & 0.436 & 0 & 0 & 1 \\
\hline Jamuna bridge & 6,237 & 0.169 & 0.375 & 0 & 0 & 1 \\
\hline Jamuna bridge (intensity) & 6,237 & 0.160 & 0.357 & 0 & 0 & 1 \\
\hline reside Dhaka & 6,237 & 0.141 & 0.348 & 0 & 0 & 1 \\
\hline marriage mig & 6,237 & 0.069 & 0.253 & 0 & 0 & 1 \\
\hline economic mig & 6,237 & 0.053 & 0.224 & 0 & 0 & 1 \\
\hline pre-marr mig & 6,237 & 0.033 & 0.180 & 0 & 0 & 1 \\
\hline same thana & 5,862 & 0.579 & 0.494 & 0 & 1 & 1 \\
\hline same district & 5,862 & 0.775 & 0.418 & 0 & 1 & 1 \\
\hline husband educ & 5,866 & 4.672 & 4.178 & 0 & 5 & 12 \\
\hline husband age & 5,726 & 36.751 & 7.159 & 19 & 36 & 66 \\
\hline husband from Dhaka & 5,862 & 0.059 & 0.236 & 0 & 0 & 1 \\
\hline husband migr Dhaka & 5,862 & 0.040 & 0.197 & 0 & 0 & 1 \\
\hline ever married & 6,237 & 0.940 & 0.238 & 0 & 1 & 1 \\
\hline married by 15 & 6,237 & 0.378 & 0.485 & 0 & 0 & 1 \\
\hline arranged marriage & 6,237 & 0.797 & 0.402 & 0 & 1 & 1 \\
\hline consang marriage & 6,237 & 0.078 & 0.268 & 0 & 0 & 1 \\
\hline own choice marriage & 6,237 & 0.068 & 0.251 & 0 & 0 & 1 \\
\hline forced marriage & 6,237 & 0.019 & 0.137 & 0 & 0 & 1 \\
\hline dowry & 5,862 & 0.386 & 0.487 & 0 & 0 & 1 \\
\hline
\end{tabular}

Note: This table presents summary statistics for the primary variables used in the analysis.

Source: Authors' construction based on WiLCAS (2014). 
In our sample, 11.5 per cent of the respondents report one migration episode or more to this industrial belt at the age of 15 or later; 6.9 per cent report at least one such migration being due to 'family reasons' and 5.2 per cent report at least one such decision being due to 'economic reasons'.

Table 2 shows descriptive statistics for all female migration episodes in the data, which we define as moving (at least) out of the village/ward for a period of six months or more. It shows that while 83 per cent of married women have experienced at least one episode of migration due to 'family reasons', only 11 per cent of married women have experienced migration due to 'economic reasons'. Furthermore, married women are much more likely to have experienced family-related migration than unmarried women (83 per cent versus 11 per cent), and among married women who have experienced any family-related migration, about 94 per cent have experienced exactly one such episode. These patterns suggest that most of the family-related migration is due to marriage, occurring at the time that the bride leaves the parental household to join the groom. Thus, most women have one shot at migration in their lives, and this migration decision is tied to their marriage decision.

In Table 3, we compare the characteristics of women who have experienced at least one episode of economic migration with those who have not. On average, the economic migrants are younger, have had more schooling, and have mothers who had more schooling. These differences are small but statistically significant. More significantly, the economic migrants are ten times more likely to be divorced or separated (16 per cent versus 1.4 per cent) and twice as likely to be widowed (2.6 per cent versus 1.2 per cent). They also report significantly lower parental landholdings (a mean of 1 acre, versus 1.44 acres for women who have never experienced economic migration).

Table 2: Migration among women aged 20-39 years

\begin{tabular}{|c|c|c|c|c|}
\hline \multirow{2}{*}{$\begin{array}{r}\text { Number of } \\
\text { episodes }\end{array}$} & \multicolumn{2}{|c|}{ Married women } & \multicolumn{2}{|c|}{ Unmarried women } \\
\hline & $\begin{array}{r}\text { Economic } \\
\text { migration } \\
(\%)\end{array}$ & $\begin{array}{r}\text { Family-related } \\
\text { migration } \\
(\%)\end{array}$ & $\begin{array}{r}\text { Economic } \\
\text { migration } \\
(\%)\end{array}$ & $\begin{array}{r}\text { Family-related } \\
\text { migration } \\
(\%)\end{array}$ \\
\hline 0 & 88.58 & 16.98 & 74.40 & 88.80 \\
\hline 1 & 9.75 & 78.30 & 23.47 & 9.87 \\
\hline 2 & 1.46 & 3.93 & 2.13 & 1.33 \\
\hline 3 & 0.19 & 0.65 & 0 & 0 \\
\hline 4 & 0.02 & 0.15 & 0 & 0 \\
\hline Observations & 5,885 & 5,885 & 375 & 375 \\
\hline
\end{tabular}

Notes: This table presents data on migration episodes of different types for married and unmarried women. A 'migration episode' means moving (at least) out of the village/ward for a period of six months or more.

Source: Authors' construction based on WiLCAS (2014). 
Table 3: Characteristics of female economic migrants

\begin{tabular}{lrrr}
\hline Variables & $\begin{array}{r}\text { \# Economic } \\
\text { migration episodes }\end{array}$ & $\begin{array}{r}\text { No } \\
\text { economic } \\
\text { migration }\end{array}$ & $\begin{array}{r}\text { Difference } \\
\text { (p-value) }\end{array}$ \\
Age (yrs) & 0 & 29.87 & -2.48 \\
& 26.87 & $(0.08)$ & $(0.00)$ \\
Schooling (yrs) & $(0.20)$ & 5.19 & 0.50 \\
& 5.69 & $(0.08)$ & $(0.00)$ \\
Secondary school (1 & $(0.20)$ & 0.47 & 0.04 \\
attended) & 0.50 & & \\
& & $(0.01)$ & $(0.07)$ \\
Currently married & $(0.02)$ & 0.92 & -0.25 \\
& 0.67 & $(0.00)$ & $(0.00)$ \\
Divorced/separated & $(0.17)$ & 0.01 & 0.15 \\
Widowed & 0.16 & $(0.002)$ & $(0.00)$ \\
Father's schooling (yrs) & $(0.013)$ & 0.012 & 0.014 \\
& 0.026 & $(0.001)$ & $(0.00)$ \\
Mother's schooling (yrs) & $(0.006)$ & 2.945 & 0.038 \\
& 2.983 & $(0.052)$ & $(0.80)$ \\
Father's landholding & $(0.052)$ & 1.581 & 0.364 \\
(acres) & 1.945 & $(0.037)$ & $(0.00)$ \\
Observations & $(0.109)$ & 1.443 & 0.441 \\
\hline
\end{tabular}

Notes: The table shows the mean value for each characteristic, with female respondents grouped according to whether they have experienced at least one episode of female migration or not. An 'economic migration' episode means moving (at least) out of the village/ward for a period of six months or more for economic reasons.

Source: Authors' construction based on WiLCAS (2014).

\section{$4 \quad$ A theoretical model of migration, labour, and marriage markets}

In this section we develop a model which allows for the fact that migration, labour, and marriage decisions are often jointly made. The model demonstrates how social constraints on the longdistance migration of single women may produce interlinkages between labour and marriage markets. We start from a two-sector trade model with migration based on Harris and Todaro (1970) and amend it to include marriage between males and females. After describing the basic elements of the model, we use it to predict how the marriage and migration behaviour of rich versus poor women will change in response to a reduction in migration costs.

\subsection{Production and labour}

The population is divided into equal measures of men and women who supply their labour inelastically $\bar{L}=2 L_{m}=2 L_{f}$. Labour may also be divided across two regions, urban $\left(L_{U}\right)$ and $\operatorname{rural}\left(L_{R}\right)$. Both men and women may work in the urban labour market $\left(L_{U}=L_{U, m}+L_{U, f}\right)$ but social norms prevent women from working in the rural labour market $\left(L_{R}=L_{R, m}\right)$. The final division is by type: both men and women are divided (equally) into rich and poor types, indicating whether they belong to rich or poor families. Poor men have no productive assets and hence earn income by selling their labour in either the rural or the urban labour market. Rich men have access to a productive asset (i.e. land) that they can use to generate an income $(r)$ without accessing labour 
markets - if they live in the rural area. If a rich man chooses to migrate to the urban area, he effectively gives up this asset and earns income by working in the urban labour market. Rich women differ from poor women only in that they can pay higher dowries and hence have first choice of marriage partners in the marriage market. Otherwise, they face the same earning opportunities: they may work in the urban labour market if they have migrated to the urban area or they may work in home production if they have remained in the rural area.

Production differs by sector. The urban sector produces a manufacturing good, $X_{M}$, according to a production function which takes labour as the only input and displays diminishing returns: $X_{M}=f\left(L_{U}\right)$, with $f^{\prime}>0, f^{\prime \prime}<0$. The rural sector produces an agricultural good, $X_{A}$, according to the following production function: $X_{A}=q\left(L_{R}, \bar{T}\right)$ (with $q^{\prime}>0, q^{\prime \prime}<0$ ), where $\bar{T}$ represents land, available in fixed supply. We assume that the price of the agricultural good, $P$, in terms of the manufacturing good is a function of the relative outputs of each sector, $P=\rho\left(\frac{X_{M}}{X_{A}}\right)$, and that the manufacturing good is the numeraire.

All factor markets are competitive, except that for home production and the labour of rich men when working on their land. In particular, the wage in the urban sector, $w_{U}$, is equal to $f^{\prime}\left(L_{U}\right)$, while the wage in the rural sector, $w_{R}$, is equal to $P \times \frac{\partial_{q}\left(L_{R}, \bar{T}\right)}{\partial L_{R}}$. We assume that $r$, the income rich men can earn from their land in the rural sector, is set exogenously and is sufficiently high that rich men can always earn more from their land than they would earn from working in the rural labour market: $r>w_{R}$. Similarly, the value of home production for women in rural areas $(h)$ is exogenously determined and assumed to be lower than the wage in the rural labour market: $h<w_{R}$.

\subsection{Marriage and migration}

\subsubsection{Marriage}

We assume that marriage and migration decisions are made simultaneously. Therefore, the migration decision depends on how resources are expected to be shared within a couple following marriage. For this purpose, we assume that utility is linear in income and intra-household allocation is determined by a separate spheres model of the household (Lundberg and Pollak 1993), where non-co-operation within the couple leads to an income loss by a fraction $\varepsilon$, and the surplus generated by co-operation, i.e. $\varepsilon\left(y_{i}+y_{j}\right)$, is shared equally within the couple. Then we obtain

$$
u_{i}=(1-\varepsilon) y_{i}+\frac{1}{2} \varepsilon\left(y_{i}+y_{j}\right)
$$

where $u_{i}$ and $y_{i}$ denote the utility and income of individual $i$ while $y_{i}$ denotes the income of their marriage partner. ${ }^{10}$ We assume the matching process in the marriage market follows a GaleShapley algorithm in which men make offers to women. Men are indifferent between marriage partners except that they (or their parents) prefer women who can pay higher dowries, while women prefer the marriage partners who give them the highest utility (taking account of intrahousehold transfers within marriage). By assumption, the daughters of rich families have higher dowries and so all men will initially make marriage offers to them. Therefore, these women will be

\footnotetext{
${ }^{10}$ In Lundberg and Pollak (1993), equilibrium levels of welfare are the result of Nash bargaining over the surplus generated from co-operation versus non-co-operation within the marriage, rather than divorce as the outside option. This assumption seems particularly relevant for the case of Bangladesh, where divorce is rare compared with most Western societies.
} 
able to choose the groom they most desire-as per the Gale-Shapley algorithm-while poorer women (who lack the income to pay dowries and are credit-constrained) must match with the remaining men. We assume that the dowry is given to the parents of the groom and hence does not enter the groom's utility function, except in so far as it breaks men's indifference in favour of women from richer families.

\subsubsection{Migration}

Individuals will prefer to migrate from the rural to the urban sector if the utility they would earn in the urban sector (net of migration costs) is greater than the utility they would enjoy if they remained in the rural sector: $u_{u}{ }_{c} \geq{ }_{u R}$, where $c>0$ is the cost of migration from the rural sector to the urban, and $u k$ is the utility earned from living in sector $k$-including intra-household transfers. ${ }^{11}$ Here, $c$ represents not just the cost of a trip to the city but the monetary equivalent of the lifetime disutility incurred from moving to a city when one has family ties and economic interests in one's village of origin. It is well documented that in developing countries, urban migrants typically retain strong ties with their extended family members in rural areas, sending and receiving transfers and making regular trips to their village of origin. Thus, if it is difficult to travel to the city from rural areas, for example because of poor infrastructure, then this has a multiplicative effect on the cost of permanent migration.

Importantly, the choice of whether to migrate is made entirely by the husbands. The prevailing social norms not only prevent women from accessing the labour market in rural areas: they also prevent them from migrating on their own to the city and even restrict their ability to make important decisions for the family (such as those involving long-term migration). Therefore, the only way that a woman can access the urban labour market is if she marries a man who subsequently migrates. ${ }^{12}$ These assumptions are motivated by the descriptive statistics on female migration patterns in Bangladesh discussed in the preceding section.

\subsubsection{Migration choices for rich and poor men}

Now let us consider the migration choices that different types of men would make, beginning with rich men. The utility that a rich man would obtain (taking account of intra-household transfers) if he remained in the rural sector, earning ${ }_{t}$ through his land while his wife earned $h$ in home production, is given by $(1-\varepsilon) r+1 / 2 \varepsilon(r+h)$, or $r+1 / 2 \varepsilon(h-r)$. If instead he were to move to the urban area and work in the urban labour market (while his wife did the same), his utility (accounting for the cost of migration as well as intra-household transfers) would be given by $w U-c$. Let us assume that $r$ is sufficiently high that rich men always prefer not to migrate:

$$
r>\frac{w_{U}-c-\varepsilon / 2 h}{(1-\varepsilon / 2)}
$$

\footnotetext{
${ }^{11}$ In order to focus exclusively on rural to urban migration, we assume that the economy starts from a position in which $u U-c \geq u R$, i.e. we do not consider cases in which $u_{R}-c \geq u U$. We also abstract away from the possibility of seasonal migration, which can serve as a risk-coping and consumption-smoothing mechanism for rural households. This is because our analysis is focused on permanent migration decisions by rural households. See, for example, Bryan et al. (2014), which deals with seasonal migration to the city from the same part of Bangladesh.

12 Note that if the marriage partners are able to commit, at the time of marriage, to making transfers to one another after their incomes are realized, then the couple would migrate if and only if doing so increases their joint income. But the ex-post bargaining we allow (as per the separate spheres model) rules out this possibility.
} 
The utility that a poor man would obtain from remaining in the rural sector (earning $w_{R}$ in the

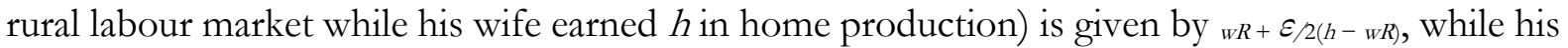
utility from moving to the urban area where both he and his wife earn $w_{U}$ would be the same as that for a rich man: ${ }_{w U}-{ }_{c}$.

\subsubsection{Equilibrium}

Given the concavity of $f(L U)$ and $q\left(L R, T_{-}^{-}\right.$, an equilibrium is guaranteed to exist in which net migration is zero because poor men are indifferent between remaining in the rural sector or migrating to the urban sector: ${ }^{13}$

$$
w_{R}+\varepsilon / 2\left(h-w_{R}\right)=w_{U}-c
$$

Note that if $c_{c}$ is large (while $\varepsilon$ is relatively small or $h$ is close to $w_{R}$ ), there may exist a substantial wage differential between the urban and rural wages in equilibrium.

\subsubsection{Marriage patterns}

Now let us consider the marriage and migration preferences of women. There are three different possibilities to consider: (1) a woman may marry a rich man and remain in the rural area (recall that rich men do not migrate by assumption); (2) a woman may marry a poor man and remain in the rural area; and (3) a woman may marry a poor man and migrate to the urban area. The woman's utility in the three cases will be given by

1.

$$
h+\varepsilon / 2(r-h)
$$

2.

$$
h+\varepsilon / 2\left(w_{R}-h\right)
$$

3.

$$
w_{U}-c
$$

respectively. We can disregard option 2 because it is clearly dominated by option 1: if a women is going to stay in the rural area, she is better off marrying a rich man. Whether a woman prefers to marry a rich man and stay in the rural area or marry a poor man who will migrate to the urban area is less clear. A woman will prefer to stay when the following condition holds:

$$
h+\varepsilon / 2(r-h)>w_{U}-c
$$

In equilibrium (i.e. when Equation 3 holds), that condition is equivalent to the following:

$$
h+\varepsilon / 2(r-h)>w+\varepsilon / 2\left(h-w_{R}\right)
$$

\footnotetext{
${ }^{13}$ In particular, if $w_{R}+\varepsilon / 2\left(h-w_{R}\right)<w_{U}-c$, then poor men (together with their wives) will migrate from the rural to the urban sector. This will cause $L_{R}$ and $X_{A}$ to go down while $L_{U}$ and $X_{M}$ go up, causing wR to go up while $w_{U}$ and $P$ go down, until the equilibrium condition is satisfied.
} 
Let us assume that we start from a position in which this condition holds, which is more likely when $h, r$, and $\varepsilon$ are relatively high, while $w_{R}$ is relatively low. Then, rich women-because they have pride of place in the marriage market - will marry rich men (and stay in the rural area), while poor women will marry poor men (and either migrate or not, depending on what the poor men do).

\subsubsection{A decline in migration costs}

Now, starting from equilibrium, imagine that there is a decline in the cost of permanent migration to the city from $c$ to $c^{\prime}$-due, for example, to improvements in transportation infrastructure. How will this affect labour and marriage markets? The effect on labour markets is straightforward: from Equation 3 we see that the value of migrating will increase so that poor men will now strictly prefer to migrate to the city and will do so, increasing $L_{U}$ and decreasing $L_{R}$ until a new equilibrium is reached with $w_{R}^{\prime}>w_{R}$ and $w_{U}^{\prime}<w_{U}$ :

$$
w_{R}^{\prime}+\varepsilon / 2\left(h-w_{R}^{\prime}\right)=w_{U}^{\prime}-c^{\prime}
$$

We retain our earlier assumption that is high enough that rich men still prefer not to migrate. ${ }^{14}$ Recall that women prefer to marry rich men and remain in the rural area as long as the inequality in 4 holds. A decline in transportation costs from to will make this condition less likely to obtainnot only in the short run but also in the new equilibrium: note that the right-hand side of inequality 4 will go up while the left-hand side is fixed. ${ }^{15}$ Thus, the decline in migration costs will affect the matches achieved on the marriage market: women will find it increasingly attractive to marry a poor man who is migrating to the urban area, and since rich women are more likely to obtain their desired matches through higher dowry payments, there will be an increasing tendency for rich women to marry poor (migrating) men.

More formally, we obtain the following result.

Proposition. Suppose that the initial parameters are such that women prefer to marry rich men and stay in the rural area over marrying a poor man and either migrating to the urban area or staying in the rural area. If migration costs decline sufficiently to reverse the inequality in 4 at the new urban equilibrium wage $w_{U}^{\prime}$, then this would:

1. increase marriage-related migration to urban areas for women from rich families, with no change for women from poor families;

2. increase urban labour force participation for women from rich families, with no change for women from poor families;

3. increase dowry payments to the migrating men (relative to the payments these potential migrants would have received if migration costs remained high).

\footnotetext{
${ }^{14}$ In other words, the inequality in 2 still holds.

${ }^{15}$ We are assuming the value of home production, $h$, and the income of rich farmers, $r$, are both unaffected by the change in transportation costs.
} 


\subsection{Identification strategy}

To identify the effects of the Jamuna Bridge on labour and marriage markets, we use a differencein-differences approach. In broad terms, we compare outcomes (i) between people who were born on the western side of the river for whom the opening of the bridge reduced journey time to the manufacturing belt around Dhaka and people born on the eastern side of the river for whom the bridge had no such effect; and (ii) between older cohorts who are likely to have made their marriage decisions before the opening of the bridge and younger cohorts who made these decisions following the opening of the bridge.

To distinguish between younger and older cohorts, we use a threshold of 16 years of age in 1998the year in which the bridge opened to the public. The rationale for this age cut-off is that the majority of the women in the older group would have been married by this age (the Bangladesh Demographic and Health Survey of 1999-2000 shows a median age of marriage of 16.1 years for women aged 20-24 years; NIPORT 2001) and, as such, their marriage-migration decisions would not have been affected by the opening of the bridge.

The same rationale does not work so well for men, who marry at a later age and also have greater flexibility in their migration decisions. Therefore, we restrict this analysis to women only, and only extend it to men when looking at the schooling outcome, as most men in the sample would have completed education by the age of 16 (as shown in Table 1, the median years of schooling for both men and women is five).

We also create a measure of 'treatment intensity' based on the fact that the reduction in travel time varied across locations on the western side of the river, depending on whether accessing the bridge involved a long detour or not. This measure is described in more detail in the next subsection.

Most of our outcomes of interest take the form of a binary variable. Therefore, we adopt a linear probability model for our main specification. It takes the following form:

$$
y_{i r c}=\delta J M_{r}+\gamma \text { Post }_{c}+\theta\left(\text { Post }_{c} \times J M_{r}\right)+d_{r}+X_{\text {irc }} \beta+\varepsilon_{\text {irc }}
$$

where $y_{i r c}$ is an outcome variable (possibly binary) for individual $i$ in region $r$ and cohort $c$; $J M_{r}$ indicates whether an individual was born in a region that the bridge connected to Dhaka; and Post $_{c}$ is a binary variable indicating whether cohort $c$ was aged 15 or younger in 1998 (in some specifications-namely those involving educational attainment-this variable may indicate whether cohort $c$ was aged 10 or younger in 1998, because decisions to drop out or remain in school may be taken prior to the age of 15). In our base specification, $J M_{r}$ takes a value of 1 if the individual was born in north-western Bangladesh and a value of 0 otherwise. ${ }^{16}$ In alternative specifications, we use a version of the $J M_{r}$ variable that captures treatment intensity, taking a value in the interval $[0,1]$ in north-western Bangladesh-details discussed in the next section-and 0 elsewhere.

\footnotetext{
${ }^{16}$ Although some parts of Rangpur division lie east of the Jamuna river, all the WiLCAS respondents born in northwestern Bangladesh (Rangpur and Rajshahi divisions) were born west of the river. Therefore the binary version of the $J M_{r}$ variable corresponds exactly with the Rangpur and Rajshahi divisions and so, in estimating the equation with division fixed effects, we drop the $J M_{r}$ variable.
} 
The variable $X_{i r c}$ is a vector of individual characteristics including age, age squared, religion, parental characteristics (education, landholdings, and occupation type), geographical distance from the individual's place of birth to the manufacturing belt around Dhaka, and a dummy indicating whether reaching the capital involves crossing a river. We do not control for the individual's education or occupation as these factors were potentially affected by access to the bridge. The variable $d_{r}$ indicates the inclusion of region fixed effects while $\varepsilon_{i r c}$ is the error term. In our primary specifications, standard errors are clustered at the subdistrict ('upazila') level, using the subdistrict where the individual was born. However, most of our results are robust to clustering at the broader district level.

Our main identification assumption is that outcomes in the areas that were affected by the opening of the Jamuna Bridge in 1998 were on a common trend with outcomes of areas that were not affected by the bridge, and thus any deviations from the trend after 1998 are due to the bridge.

\subsection{Measure of treatment intensity}

One of the key variables in our analysis is a measure of the 'intensity of the treatment' of having access to the Jamuna Bridge to travel to Dhaka. Except for women born in north-western Bangladesh, this measure is set to 0 for everyone, as they would not need to cross the Jamuna river to travel to Dhaka. For women born in north-western Bangladesh, we also set it to 0 for the older cohorts, i.e. those aged 16 or older when the bridge opened in 1998.

For the younger women born in north-western Bangladesh, we construct a formula for treatment intensity aimed at capturing the percentage reduction in travel time to Dhaka due to the construction of the bridge, as follows:

$$
\zeta=\max \left\{0,1-\frac{(a+b)}{(c+300)}\right\}
$$

where $a=$ geographical distance (in kilometres) from the respondent's place of birth in northwestern Bangladesh to Dhaka, $b=$ geographical distance from Jamuna Bridge to Dhaka, and $c=$ geographical distance from the place of birth to Dhaka. The number 300 appears in the formula as we assume that crossing the Jamuna river in the absence of a bridge-e.g. On a ferry-would take, on average, the same amount of time as travelling 300 kilometres. ${ }^{17}$ Figure 1 shows the treatment intensity diagrammatically for the towns of Bogra and Pabna in north-western Bangladesh, while the distribution of values of the treatment intensity in all the WiLCAS clusters in north-western Bangladesh are shown in Figure 2.

\footnotetext{
17 To arrive at this equivalence we assume that the average time taken to cross the Jamuna river prior the bridge construction was 10 hours (including time queuing for the ferry) and that the average travel speed on roads is 30 kilometers per hour. Our estimates are robust to variations in these assumptions.
} 
Figure 1: Measure of treatment intensity

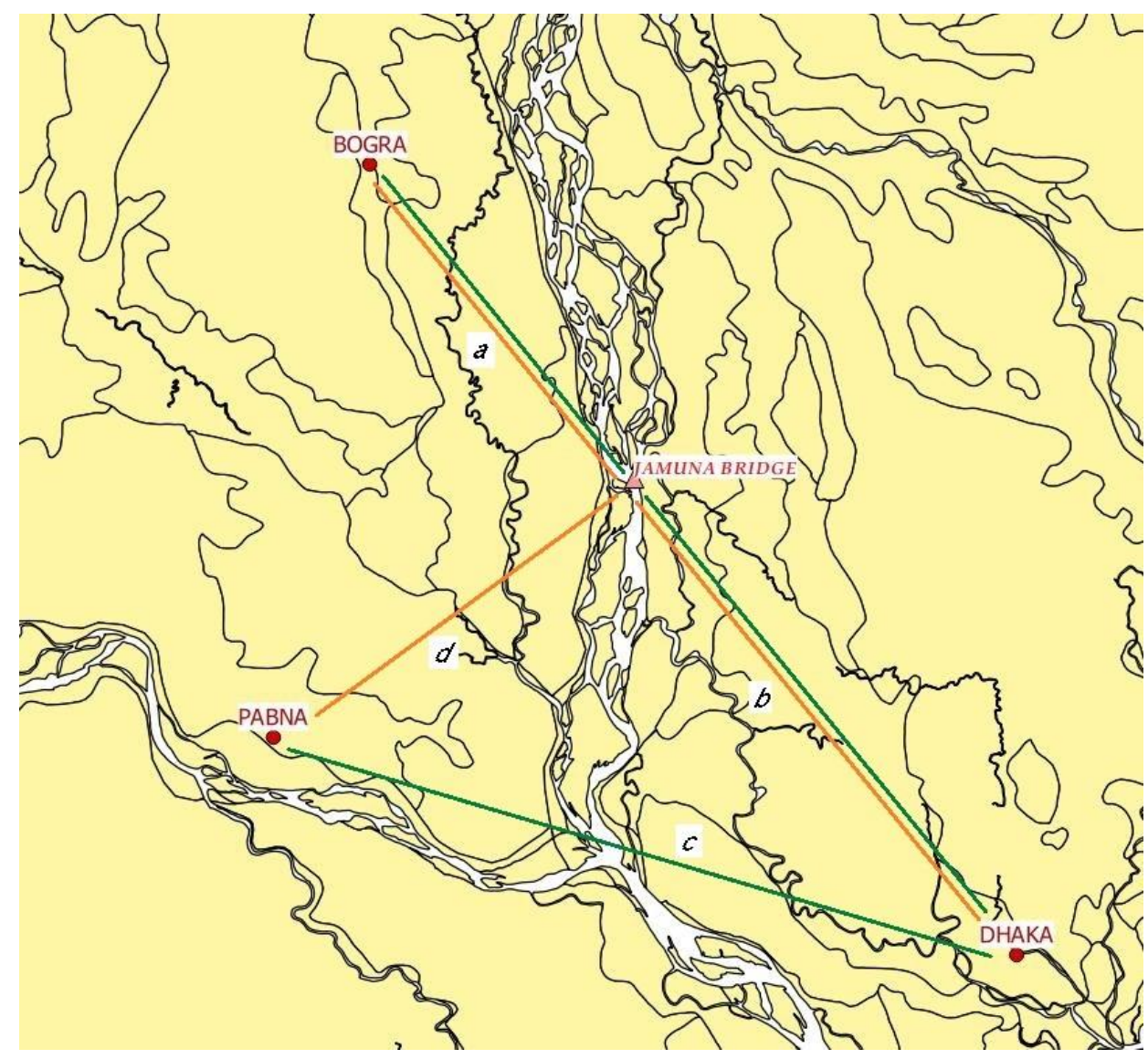

Town

Treatment intensity

Bogra

$$
\max \left\{0,1-\frac{a+b}{a+b+300}\right\}
$$

Pabna

$$
\max \left\{0,1-\frac{d+b}{c+300}\right\}
$$

Note: This figure illustrates the formula for the treatment intensity variable using the towns of Bogra and Pabna as examples.

Source: Authors' construction based on WiLCAS (2014).

For women 'exposed' to the Jamuna Bridge, the treatment intensity variable has a median value of 0.575 and a range of 0.447 to 0.736 . In other words, the reduction in travel time varies from 44.7 per cent for women born in villages very distant from the bridge to 73.6 per cent for women born in villages close to the bridge or villages from which travelling to Dhaka via the bridge would not involve a long detour.

We use the geographical distance rather than the road distance for the treatment intensity variable. Although we have information about respondents' place of residence in their adolescence (around the time of their marriage and migration decisions), we use place of birth in the formula as it is more likely to be exogenous to the construction of the bridge. 
Figure 2: Jamuna Bridge treatment intensity in north-western Bangladesh

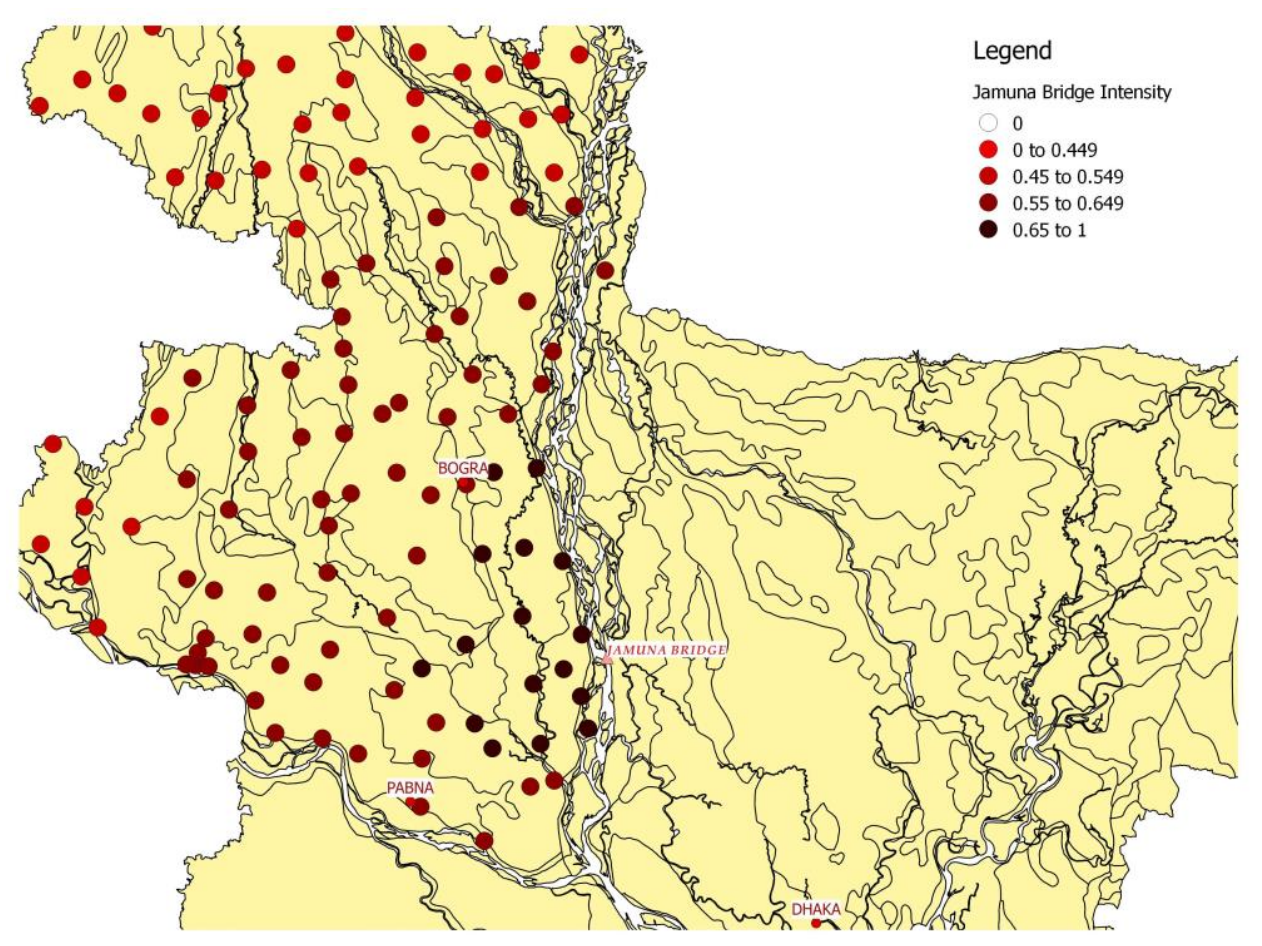

Note: This figure illustrates the variation in the treatment intensity variable across all the sample villages in northwestern Bangladesh. The treatment intensity is equal to 0 in other parts of Bangladesh.

Source: Authors' construction based on WiLCAS (2014).

\section{Results}

One of the insights from our theoretical analysis is that if the opening of the Jamuna Bridge affects female migration, it may have a stronger effect on women whose families are able to pay higher dowries. To capture these differential effects, we split the sample of women in two according to their parental landholdings. More specifically, we estimate Equation 6 separately for women whose parents had half an acre or more of cultivable land when the daughter in question was aged 12 (54 per cent of the sample) and for women below this threshold. Half an acre of land is a criterion widely used for poverty-targeted programmes, including a number of well-known initiatives in Bangladesh such as Grameen Bank's original microcredit programme (Pitt and Khandker 1998) and the Bangladesh government's Food for Education programme (Meng and Ryan 2010).

\subsection{Pre-existing trends}

Before presenting the estimated coefficients for Equation 6 for our outcomes of interest, we check whether the trends in these variables for the older cohorts (who experienced marriage prior to the bridge opening) are consistent with the identifying assumptions described in Section 5. Figures 3 and 4 show, for each of our outcome variables, three-year moving averages across cohorts born between 1975 and 1994, grouped according to whether or not they were born in north-western Bangladesh ('Jamuna Region').

The outcomes include binary variables indicating whether the respondent (i) currently resides in the Dhaka region; (ii) has ever engaged in marriage-related migration towards Dhaka; (iii) has ever engaged in economic migration towards Dhaka; (iv) has ever been employed in the ready-made 
garments sector; (v) is married to a man from the same district as herself; (vi) has a husband who has migrated to the Dhaka region; and (vii) has attended secondary school. They also include continuous variables indicating (viii) the respondents' years of schooling; and (ix) the natural log of dowry payments made by the respondent (or her family). Figure 3 shows the trends for respondents whose fathers had less than half an acre of land and Figure 4 the corresponding trends for respondents above this threshold. A dashed vertical line in each graph separates the older cohorts (born before 1983 and at least 16 years of age when the bridge opened) and the younger cohorts. For the older cohorts, we do not observe any clear differences in trends between the Jamuna region and elsewhere in either Figure 3 or Figure 4.

Figure 3: All outcomes (by Jamuna status for respondents with $<$ half an acre)
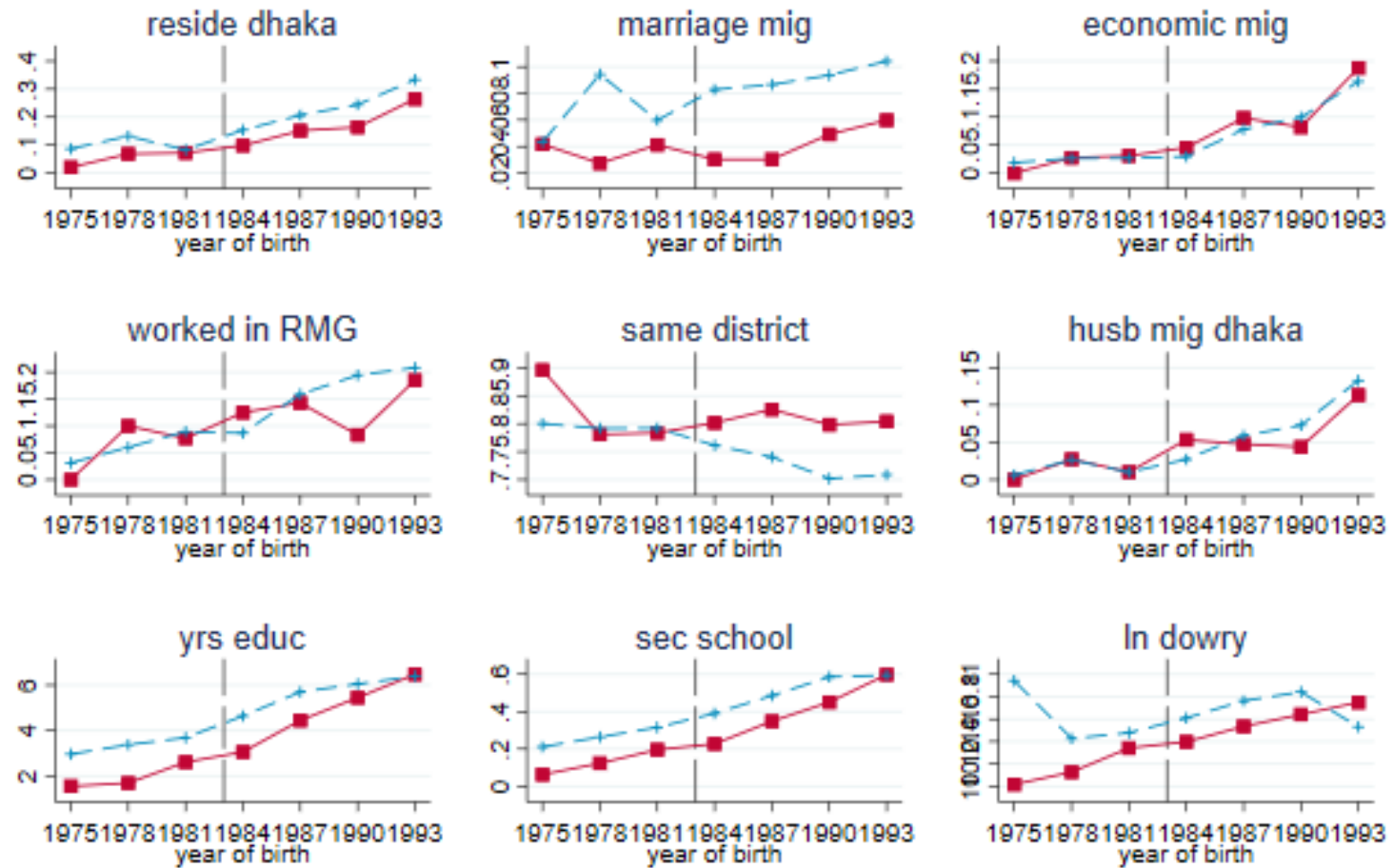

Jamuna Region

--+-- Non-Jamuna Region

Notes: This figure graphs mean outcomes by birth cohort for respondents whose fathers owned less than half an acre of land. Outcomes for respondents who were born in Rajshahi or Rangpur division are graphed with a solid red line, while outcomes for other respondents are shown with a dashed blue line. Birth cohorts are grouped into three-year intervals to reduce noise (e.g. individuals born in 1980, 1981, and 1982 are grouped into the same cohort).

Source: Authors' construction based on WiLCAS (2014).

On the other hand, we do observe some divergence in trends for the younger cohorts, in particular for residence in Dhaka, work in ready-made garments, and husband's migration to Dhaka in Figure 4 , suggesting that the opening of the bridge affected at least some outcomes for women born in north-western Bangladesh. 
Figure 4: All outcomes (by Jamuna status for respondents with $>$ half an acre)
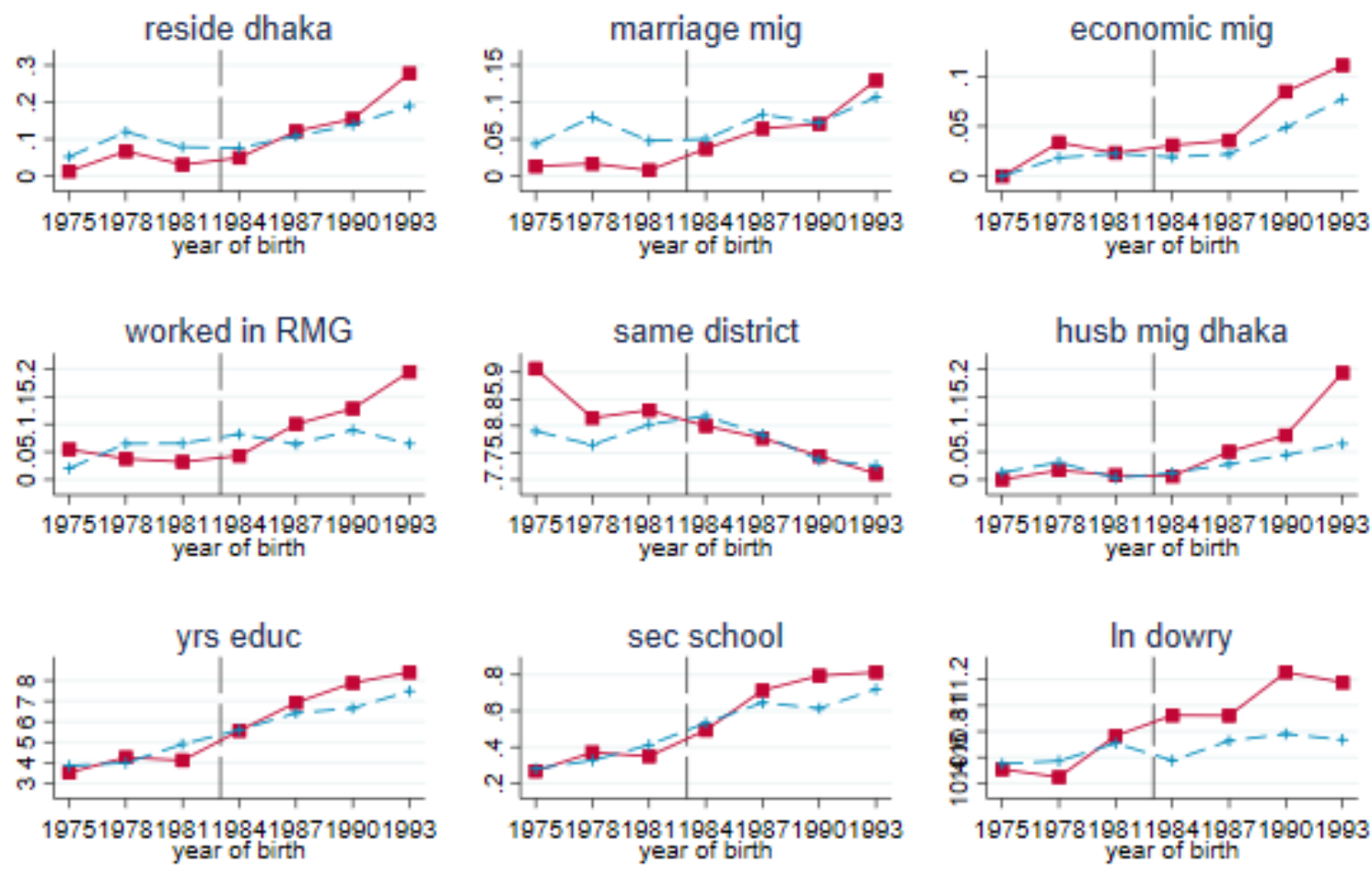

\section{$\longrightarrow$ - Jamuna Region $\quad$ - -+- - Non-Jamuna Region}

Note: This figure graphs mean outcomes by birth cohort for respondents whose fathers owned more than half an acre of land. Outcomes for respondents who were born in Rajshahi or Rangpur division are graphed with a solid red line, while outcomes for other respondents are shown with a dashed blue line. Birth cohorts are grouped into three-year intervals to reduce noise (e.g. individuals born in 1980, 1981, and 1982 are grouped into the same cohort).

Source: Authors' construction based on WiLCAS (2014).

\subsection{Regression results}

The results for both sets of women support the decision to split the sample by family wealth and are generally in line with the theoretical framework sketched above. We begin by discussing the results for women from relatively poorer families, as presented in Tables 4 to 8 . The tables depict the effect of the bridge on the available measures of these women's migration, work, marriage, dowry, and education outcomes. The odd columns contain estimates using the binary treatment indicator $\left(\mathrm{JM}\right.$ bridge $\times$ post, which corresponds to the term $\left(\right.$ Post $\left._{c} \times J M_{R}\right)$ in the regression specification from Equation 6) while even columns present estimates using the continuous version of the treatment $(\mathrm{JM}$ bridge (intensity) $\times$ post). We focus our discussion below on the coefficients of these two measures of the treatment effect, although the tables also report coefficients on the distance to the nearest RMG factory (in tens of kilometres), whether individuals need to cross any river (including the Jamuna) to reach Dhaka, whether they were young enough to be affected by the bridge construction (i.e. the Post $_{c}$ term in the regression specification), their age, and their age squared. The regression specifications also include all of the variables discussed in the previous section-including division fixed effects-but for convenience these are not shown. Note that coefficients for the JM bridge variable are absent from the odd columns as these effects are subsumed in the division fixed effects (see footnote 16 for further details). 
Table 4: Migration outcomes for respondents with parental landholdings of less than half an acre

\begin{tabular}{|c|c|c|c|c|c|c|c|c|}
\hline & $\begin{array}{c}\text { (1) } \\
\text { reside dhaka }\end{array}$ & $\begin{array}{c}\text { (2) } \\
\text { reside dhaka }\end{array}$ & $\begin{array}{c}\text { (3) } \\
\text { marriage mig }\end{array}$ & $\begin{array}{c}\text { (4) } \\
\text { marriage mig }\end{array}$ & $\begin{array}{c}\text { (5) } \\
\text { economic mig }\end{array}$ & $\begin{array}{c}\text { (6) } \\
\text { economic mig }\end{array}$ & $\begin{array}{c}\text { (7) } \\
\text { migr dhaka }\end{array}$ & $\begin{array}{c}\text { (8) } \\
\text { migr dhaka }\end{array}$ \\
\hline JM bridge $\mathrm{X}_{\text {post }}$ & $\begin{array}{l}-0.014 \\
(0.027)\end{array}$ & & $\begin{array}{l}-0.014 \\
(0.020)\end{array}$ & & $\begin{array}{c}0.017 \\
(0.019)\end{array}$ & & $\begin{array}{l}0.007 \\
(0.025)\end{array}$ & \\
\hline $\begin{array}{l}\mathrm{JM} \text { bridge } \\
\text { (intensity) } \mathrm{X}_{\text {post }}\end{array}$ & & $\begin{array}{r}-0.003 \\
(0.045)\end{array}$ & & $\begin{array}{r}-0.009 \\
(0.033)\end{array}$ & & $\begin{array}{c}0.031 \\
(0.032)\end{array}$ & & $\begin{array}{c}0.029 \\
(0.042)\end{array}$ \\
\hline $\begin{array}{l}\mathrm{JM} \text { bridge } \\
\text { (intensity) }\end{array}$ & & $\begin{array}{l}-0.642^{*} \\
(0.372)\end{array}$ & & $\begin{array}{c}-0.495^{\cdots} \\
(0.186)\end{array}$ & & $\begin{array}{c}0.253 \\
(0.218)\end{array}$ & & $\begin{array}{l}-0.322 \\
(0.290)\end{array}$ \\
\hline born post 1982 & $\begin{array}{c}0.025 \\
(0.022)\end{array}$ & $\begin{array}{c}0.021 \\
(0.022)\end{array}$ & $\begin{array}{r}-0.004 \\
(0.020)\end{array}$ & $\begin{array}{l}-0.007 \\
(0.020)\end{array}$ & $\begin{array}{r}-0.017 \\
(0.014)\end{array}$ & $\begin{array}{l}-0.017 \\
(0.014)\end{array}$ & $\begin{array}{l}-0.023 \\
(0.022)\end{array}$ & $\begin{array}{l}-0.026 \\
(0.022)\end{array}$ \\
\hline dist to RMG (10km) & $\begin{array}{c}-0.010 \cdots * \\
(0.002)\end{array}$ & $\begin{array}{c}-0.012 \cdots \\
(0.003)\end{array}$ & $\begin{array}{c}-0.005^{\cdots *} \\
(0.001)\end{array}$ & $\begin{array}{c}-0.007 \cdots * \\
(0.002)\end{array}$ & $\begin{array}{c}0.000 \\
(0.001)\end{array}$ & $\begin{array}{c}0.001 \\
(0.001)\end{array}$ & $\begin{array}{c}-0.006 \cdots * \\
(0.002)\end{array}$ & $\begin{array}{c}-0.006 \cdots \\
(0.002)\end{array}$ \\
\hline river cross & $\begin{array}{c}-0.238 \cdots \\
(0.056)\end{array}$ & $\begin{array}{c}-0.237^{\cdots} \\
(0.055)\end{array}$ & $\begin{array}{c}-0.124^{\cdots *} \\
(0.040)\end{array}$ & $\begin{array}{c}-0.123^{\cdots *} \\
(0.040)\end{array}$ & $\begin{array}{r}-0.022 \\
(0.033)\end{array}$ & $\begin{array}{l}-0.022 \\
(0.033)\end{array}$ & $\begin{array}{c}-0.132^{* \cdots} \\
(0.047)\end{array}$ & $\begin{array}{c}-0.132^{\cdots} \\
(0.047)\end{array}$ \\
\hline age & $\begin{array}{c}-0.064 \cdots \\
(0.013)\end{array}$ & $\begin{array}{c}-0.065^{\cdots *} \\
(0.013)\end{array}$ & $\begin{array}{l}-0.002 \\
(0.009)\end{array}$ & $\begin{array}{l}-0.003 \\
(0.009)\end{array}$ & $\begin{array}{c}-0.043^{\cdots} \cdots \\
(0.010)\end{array}$ & $\begin{array}{c}-0.043^{\cdots} \cdots \\
(0.010)\end{array}$ & $\begin{array}{c}-0.050^{\cdots *} \\
(0.012)\end{array}$ & $\begin{array}{c}-0.051 \cdots \\
(0.012)\end{array}$ \\
\hline age sq & $\begin{array}{l}0.001 \cdots \\
(0.000)\end{array}$ & $\begin{array}{c}0.001 \cdots \\
(0.000)\end{array}$ & $\begin{array}{c}0.000 \\
(0.000)\end{array}$ & $\begin{array}{c}0.000 \\
(0.000)\end{array}$ & $\begin{array}{c}0.001^{\cdots \cdots} \\
(0.000)\end{array}$ & $\begin{array}{c}0.001 \cdots \\
(0.000)\end{array}$ & $\begin{array}{c}0.001 \cdots \\
(0.000)\end{array}$ & $\begin{array}{c}0.001 \cdots \\
(0.000)\end{array}$ \\
\hline Constant & $\begin{array}{l}1.555^{\cdots} \cdots \\
(0.188) \\
\end{array}$ & $\begin{array}{c}1.578^{\cdots *} \\
(0.188)\end{array}$ & $\begin{array}{l}0.319^{* *} \\
(0.130)\end{array}$ & $\begin{array}{l}0.337^{* *} \\
(0.130) \\
\end{array}$ & $\begin{array}{c}0.879^{\cdots * *} \\
(0.149)\end{array}$ & $\begin{array}{c}0.870^{* \cdots *} \\
(0.149)\end{array}$ & $\begin{array}{c}1.250^{\cdots \cdots} \\
(0.175)\end{array}$ & $\begin{array}{c}1.262^{\cdots \cdots} \\
(0.176)\end{array}$ \\
\hline Observations & 2903 & 2903 & 2903 & 2903 & 2903 & 2903 & 2903 & 2903 \\
\hline
\end{tabular}

Note: Robust standard errors clustered by subdistrict in parentheses.

Source: Authors' construction based on WiLCAS (2014).

Table 5: Work outcomes for respondents with parental landholdings of less than half an acre

\begin{tabular}{|c|c|c|}
\hline & $\begin{array}{c}\text { (1) } \\
\text { worked in RMG }\end{array}$ & $\begin{array}{c}(2) \\
\text { worked in RMG }\end{array}$ \\
\hline JM bridge $\mathrm{X}$ post & $\begin{array}{l}-0.023 \\
(0.036)\end{array}$ & \\
\hline $\begin{array}{l}\text { JM bridge } \\
\text { (intensity) } \mathrm{X}_{\text {post }}\end{array}$ & & $\begin{array}{l}-0.041 \\
(0.061)\end{array}$ \\
\hline $\begin{array}{l}\text { JM bridge } \\
\text { (intensity) }\end{array}$ & & $\begin{array}{c}0.449 \\
(0.364)\end{array}$ \\
\hline born post 1982 & $\begin{array}{l}-0.001 \\
(0.030)\end{array}$ & $\begin{array}{l}-0.001 \\
(0.030)\end{array}$ \\
\hline dist to RMG (10km) & $\begin{array}{l}-0.000 \\
(0.002)\end{array}$ & $\begin{array}{c}0.001 \\
(0.002)\end{array}$ \\
\hline river cross & $\begin{array}{c}0.011 \\
(0.049)\end{array}$ & $\begin{array}{c}0.010 \\
(0.049)\end{array}$ \\
\hline age & $\begin{array}{l}-0.022 \\
(0.016)\end{array}$ & $\begin{array}{l}-0.022 \\
(0.016)\end{array}$ \\
\hline age sq & $\begin{array}{c}0.000 \\
(0.000)\end{array}$ & $\begin{array}{c}0.000 \\
(0.000)\end{array}$ \\
\hline Constant & $\begin{array}{c}0.661^{\cdots *} \\
(0.244)\end{array}$ & $\begin{array}{c}0.647^{* * *} \\
(0.246)\end{array}$ \\
\hline Observations & 1645 & 1645 \\
\hline
\end{tabular}

Notes: $p<0.10,{ }^{* *} p<0.05,{ }^{* * *} p<0.01$; robust standard errors clustered by subdistrict in parentheses.

Source: Authors' construction based on WiLCAS (2014). 
Table 6: Marriage outcomes for respondents with parental landholdings of less than half an acre

\begin{tabular}{|c|c|c|c|c|c|c|}
\hline & $\begin{array}{c}\text { (1) } \\
\text { same district }\end{array}$ & $\begin{array}{c}\text { (2) } \\
\text { same district }\end{array}$ & $\begin{array}{c}\text { (3) } \\
\text { husb dhaka }\end{array}$ & $\begin{array}{c}\text { (4) } \\
\text { husb dhaka }\end{array}$ & $\begin{array}{c}\text { (5) } \\
\text { husb mig dhaka }\end{array}$ & $\begin{array}{c}\text { (6) } \\
\text { husb mig dhaka }\end{array}$ \\
\hline JM bridge $\mathrm{X}$ post & $\begin{array}{c}0.063 \\
(0.039)\end{array}$ & & $\begin{array}{l}-0.018 \\
(0.013)\end{array}$ & & $\begin{array}{l}-0.003 \\
(0.015)\end{array}$ & \\
\hline $\begin{array}{l}\text { JM bridge } \\
\text { (intensity) X post }\end{array}$ & & $\begin{array}{l}0.118^{*} \\
(0.067)\end{array}$ & & $\begin{array}{l}-0.014 \\
(0.021)\end{array}$ & & $\begin{array}{l}-0.006 \\
(0.026)\end{array}$ \\
\hline $\begin{array}{l}\text { JM bridge } \\
\text { (intensity) }\end{array}$ & & $\begin{array}{c}0.056 \\
(0.439)\end{array}$ & & $\begin{array}{c}-1.027^{* * *} \\
(0.252)\end{array}$ & & $\begin{array}{c}0.250 \\
(0.186)\end{array}$ \\
\hline born post 1982 & $\begin{array}{l}-0.002 \\
(0.033)\end{array}$ & $\begin{array}{l}-0.003 \\
(0.033)\end{array}$ & $\begin{array}{c}0.018 \\
(0.018)\end{array}$ & $\begin{array}{c}0.015 \\
(0.018)\end{array}$ & $\begin{array}{c}0.008 \\
(0.012)\end{array}$ & $\begin{array}{c}0.009 \\
(0.012)\end{array}$ \\
\hline dist to $\mathrm{RMG}(10 \mathrm{~km})$ & $\begin{array}{l}0.005^{* *} \\
(0.002)\end{array}$ & $\begin{array}{l}0.006^{*} \\
(0.003)\end{array}$ & $\begin{array}{c}-0.010^{* *} \\
(0.002)\end{array}$ & $\begin{array}{c}-0.013 * * \\
(0.003)\end{array}$ & $\begin{array}{l}-0.000 \\
(0.001)\end{array}$ & $\begin{array}{c}0.000 \\
(0.001)\end{array}$ \\
\hline river cross & $\begin{array}{c}0.016 \\
(0.058)\end{array}$ & $\begin{array}{c}0.016 \\
(0.058)\end{array}$ & $\begin{array}{c}-0.276^{* *} \\
(0.044)\end{array}$ & $\begin{array}{c}-0.274^{* * *} \\
(0.044)\end{array}$ & $\begin{array}{l}-0.002 \\
(0.029)\end{array}$ & $\begin{array}{l}-0.002 \\
(0.029)\end{array}$ \\
\hline age & $\begin{array}{c}0.000 \\
(0.016)\end{array}$ & $\begin{array}{c}0.000 \\
(0.016)\end{array}$ & $\begin{array}{l}0.018 * * \\
(0.008)\end{array}$ & $\begin{array}{l}0.018^{* *} \\
(0.008)\end{array}$ & $\begin{array}{c}-0.039^{* * *} \\
(0.010)\end{array}$ & $\begin{array}{c}-0.039 * * \\
(0.010)\end{array}$ \\
\hline age sq & $\begin{array}{c}0.000 \\
(0.000)\end{array}$ & $\begin{array}{c}0.000 \\
(0.000)\end{array}$ & $\begin{array}{c}-0.000^{* *} \\
(0.000)\end{array}$ & $\begin{array}{c}-0.000^{* *} \\
(0.000)\end{array}$ & $\begin{array}{c}0.001^{* *} \\
(0.000)\end{array}$ & $\begin{array}{c}0.001^{* * *} \\
(0.000)\end{array}$ \\
\hline Constant & $\begin{array}{l}0.557^{* *} \\
(0.229)\end{array}$ & $\begin{array}{l}0.554^{* *} \\
(0.231)\end{array}$ & $\begin{array}{c}0.060 \\
(0.111)\end{array}$ & $\begin{array}{c}0.091 \\
(0.111)\end{array}$ & $\begin{array}{c}0.726^{* *} \\
(0.158)\end{array}$ & $\begin{array}{c}0.719^{* * *} \\
(0.158)\end{array}$ \\
\hline Observations & 2702 & 2702 & 2702 & 2702 & 2702 & 2702 \\
\hline
\end{tabular}

Notes: $p<0.10,{ }^{* *} p<0.05,{ }^{* * *} p<0.01$; robust standard errors clustered by subdistrict in parentheses.

Source: Authors' construction based on WiLCAS (2014). 
Table 7: Dowry outcomes for respondents with parental landholdings of less than half an acre

\begin{tabular}{|c|c|c|c|c|}
\hline & $\begin{array}{c}(1) \\
\text { dowry }\end{array}$ & $\begin{array}{c}(2) \\
\text { dowry }\end{array}$ & $\begin{array}{c}\text { (3) } \\
\text { In real dowry }\end{array}$ & $\begin{array}{c}(4) \\
\text { In real dowry }\end{array}$ \\
\hline JM bridge $\mathrm{X}$ post & $\begin{array}{c}0.146^{* * *} \\
(0.049)\end{array}$ & & $\begin{array}{c}0.195 \\
(0.121)\end{array}$ & \\
\hline $\begin{array}{l}\text { JM bridge } \\
\text { (intensity) X post }\end{array}$ & & $\begin{array}{c}0.220^{* *} \\
(0.083)\end{array}$ & & $\begin{array}{c}0.311 \\
(0.211)\end{array}$ \\
\hline $\begin{array}{l}\text { JM bridge } \\
\text { (intensity) }\end{array}$ & & $\begin{array}{l}1.249^{* *} \\
(0.507)\end{array}$ & & $\begin{array}{c}-3.013^{* *} \\
(1.191)\end{array}$ \\
\hline born post 1982 & $\begin{array}{l}-0.071^{*} \\
(0.039)\end{array}$ & $\begin{array}{l}-0.064 \\
(0.039)\end{array}$ & $\begin{array}{c}0.096 \\
(0.133)\end{array}$ & $\begin{array}{c}0.090 \\
(0.132)\end{array}$ \\
\hline dist to RMG $(10 \mathrm{~km})$ & $\begin{array}{c}0.001 \\
(0.003)\end{array}$ & $\begin{array}{l}0.005^{*} \\
(0.003)\end{array}$ & $\begin{array}{l}-0.008 \\
(0.007)\end{array}$ & $\begin{array}{c}-0.019 * * \\
(0.009)\end{array}$ \\
\hline river cross & $\begin{array}{l}-0.088^{*} \\
(0.051)\end{array}$ & $\begin{array}{l}-0.090^{*} \\
(0.051)\end{array}$ & $\begin{array}{l}-0.156 \\
(0.145)\end{array}$ & $\begin{array}{l}-0.154 \\
(0.142)\end{array}$ \\
\hline age & $\begin{array}{c}0.065^{* * *} \\
(0.018)\end{array}$ & $\begin{array}{c}0.066^{* *} \\
(0.018)\end{array}$ & $\begin{array}{l}-0.035 \\
(0.064)\end{array}$ & $\begin{array}{l}-0.037 \\
(0.064)\end{array}$ \\
\hline age sq & $\begin{array}{c}-0.001^{* \cdot \cdot} \\
(0.000)\end{array}$ & $\begin{array}{c}-0.001^{* * *} \\
(0.000)\end{array}$ & $\begin{array}{c}0.000 \\
(0.001)\end{array}$ & $\begin{array}{c}0.000 \\
(0.001)\end{array}$ \\
\hline Constant & $\begin{array}{l}-0.339 \\
(0.251)\end{array}$ & $\begin{array}{l}-0.381 \\
(0.252)\end{array}$ & $\begin{array}{c}11.211^{* * *} \\
(0.806)\end{array}$ & $\begin{array}{c}11.343^{* * *} \\
(0.816)\end{array}$ \\
\hline Observations & 2702 & 2702 & 1044 & 1044 \\
\hline
\end{tabular}

Notes: $p<0.10,{ }^{* *} p<0.05,{ }^{* * *} p<0.01$; robust standard errors clustered by subdistrict in parentheses; including only respondents with positive dowry amounts.

Source: Authors' construction based on WiLCAS (2014). 
Table 8: Education outcomes for respondents with parental landholdings of less than half an acre

\begin{tabular}{|c|c|c|c|c|c|c|c|c|}
\hline & $\begin{array}{c}(1) \\
\text { yrs educ }\end{array}$ & $\begin{array}{c}(2) \\
\text { yrs educ }\end{array}$ & $\begin{array}{c}(3) \\
\text { yrs educ }\end{array}$ & $\begin{array}{c}(4) \\
\text { yrs educ }\end{array}$ & $\begin{array}{c}\text { (5) } \\
\text { sec_school }\end{array}$ & $\begin{array}{c}(6) \\
\text { sec_school }\end{array}$ & $\begin{array}{c}(7) \\
\text { sec_school }\end{array}$ & $\begin{array}{c}(8) \\
\text { sec_school }\end{array}$ \\
\hline JM bridge $\mathrm{X}$ post & $\begin{array}{c}0.398 \\
(0.289)\end{array}$ & & & & $\begin{array}{c}0.009 \\
(0.035)\end{array}$ & & & \\
\hline $\begin{array}{l}\text { JM bridge } \\
\text { (intensity) } \mathrm{X} \text { post }\end{array}$ & & $\begin{array}{l}0.885^{*} \\
(0.513)\end{array}$ & & & & $\begin{array}{c}0.041 \\
(0.062)\end{array}$ & & \\
\hline $\begin{array}{l}\text { JM bridge } \mathrm{X} \text { post } \\
\text { (10 yrs) }\end{array}$ & & & $\begin{array}{c}0.985^{* \cdots} \\
(0.280)\end{array}$ & & & & $\begin{array}{c}0.053 \\
(0.038)\end{array}$ & \\
\hline $\begin{array}{l}\text { JM bridge } \\
\text { (intensity) X post ( } 10 \mathrm{yrs})\end{array}$ & & & & $\begin{array}{c}1.795 * * \\
(0.494)\end{array}$ & & & & $\begin{array}{c}0.103 \\
(0.067)\end{array}$ \\
\hline $\begin{array}{l}\text { JM bridge } \\
\text { (intensity) }\end{array}$ & & $\begin{array}{c}-12.218^{* * *} \\
(3.004)\end{array}$ & & $\begin{array}{c}-12.502^{* *} \\
(2.937)\end{array}$ & & $\begin{array}{c}-1.640^{* * *} \\
(0.397)\end{array}$ & & $\begin{array}{c}-1.656^{* *} \\
(0.387)\end{array}$ \\
\hline born post 1982 & $\begin{array}{c}0.190 \\
(0.277)\end{array}$ & $\begin{array}{c}0.152 \\
(0.277)\end{array}$ & & & $\begin{array}{l}-0.015 \\
(0.037)\end{array}$ & $\begin{array}{l}-0.020 \\
(0.037)\end{array}$ & & \\
\hline born post 1987 & & & $\begin{array}{l}-0.223 \\
(0.261)\end{array}$ & $\begin{array}{l}-0.257 \\
(0.261)\end{array}$ & & & $\begin{array}{c}0.016 \\
(0.039)\end{array}$ & $\begin{array}{c}0.012 \\
(0.039)\end{array}$ \\
\hline dist to RMG (10km) & $\begin{array}{l}-0.032^{*} \\
(0.019)\end{array}$ & $\begin{array}{c}-0.066^{* * *} \\
(0.022)\end{array}$ & $\begin{array}{l}-0.032^{*} \\
(0.019)\end{array}$ & $\begin{array}{c}-0.067^{* * *} \\
(0.022)\end{array}$ & $\begin{array}{c}-0.005^{* *} \\
(0.002)\end{array}$ & $\begin{array}{c}-0.010^{* \cdots} \\
(0.003)\end{array}$ & $\begin{array}{l}-0.005^{* *} \\
(0.002)\end{array}$ & $\begin{array}{c}-0.010^{* *} \\
(0.003)\end{array}$ \\
\hline river cross & $\begin{array}{l}0.896^{* *} \\
(0.368)\end{array}$ & $\begin{array}{l}0.912^{* *} \\
(0.364)\end{array}$ & $\begin{array}{l}0.874^{* *} \\
(0.365)\end{array}$ & $\begin{array}{l}0.890^{* *} \\
(0.362)\end{array}$ & $\begin{array}{l}0.101^{* *} \\
(0.042)\end{array}$ & $\begin{array}{l}0.103^{* *} \\
(0.042)\end{array}$ & $\begin{array}{l}0.100^{* *} \\
(0.042)\end{array}$ & $\begin{array}{l}0.103^{* *} \\
(0.041)\end{array}$ \\
\hline age & $\begin{array}{c}-0.250^{* *} \\
(0.127)\end{array}$ & $\begin{array}{c}-0.260^{* *} \\
(0.126)\end{array}$ & $\begin{array}{l}-0.193 \\
(0.145)\end{array}$ & $\begin{array}{l}-0.210 \\
(0.144)\end{array}$ & $\begin{array}{c}-0.029^{*} \\
(0.017)\end{array}$ & $\begin{array}{c}-0.030^{*} \\
(0.017)\end{array}$ & $\begin{array}{l}-0.020 \\
(0.021)\end{array}$ & $\begin{array}{l}-0.023 \\
(0.020)\end{array}$ \\
\hline age sq & $\begin{array}{c}0.001 \\
(0.002)\end{array}$ & $\begin{array}{c}0.001 \\
(0.002)\end{array}$ & $\begin{array}{l}-0.001 \\
(0.002)\end{array}$ & $\begin{array}{l}-0.000 \\
(0.002)\end{array}$ & $\begin{array}{c}0.000 \\
(0.000)\end{array}$ & $\begin{array}{c}0.000 \\
(0.000)\end{array}$ & $\begin{array}{l}-0.000 \\
(0.000)\end{array}$ & $\begin{array}{c}0.000 \\
(0.000)\end{array}$ \\
\hline Constant & $\begin{array}{c}10.753^{* * *} \\
(1.718)\end{array}$ & $\begin{array}{c}11.150^{* * *} \\
(1.711)\end{array}$ & $\begin{array}{c}10.464^{* * *} \\
(2.264)\end{array}$ & $\begin{array}{c}10.974^{\cdots} \\
(2.258)\end{array}$ & $\begin{array}{c}1.146^{* * *} \\
(0.237)\end{array}$ & $\begin{array}{c}1.201^{* * *} \\
(0.236)\end{array}$ & $\begin{array}{c}0.972^{* * *} \\
(0.332)\end{array}$ & $\begin{array}{c}1.045^{* * *} \\
(0.330)\end{array}$ \\
\hline Observations & 2903 & 2903 & 2903 & 2903 & 2903 & 2903 & 2903 & 2903 \\
\hline
\end{tabular}

Notes: $p<0.10,{ }^{* *} p<0.05,{ }^{* * *} p<0.01$; robust standard errors clustered by subdistrict in parentheses.

Source: Authors' construction based on WiLCAS (2014).

The results show no effect on the migration or work outcomes for women from poorer families in the north-western divisions (Tables 4 and 5). Yet it is evident from the estimates that being born in a region separated from Dhaka by a major river serves as a significant impediment to migration (the rate of migration is lower by about 13 percentage points). The bridge does, however, appear to have had an impact on these women's marriage outcomes: they are now 14.6 percentage points more likely to pay a dowry than before-although, conditional on paying a dowry, the amount of dowry paid does not change appreciably (Table 7). The bridge also appears to have affected incentives to invest in human capital: Table 8 shows that poor women aged ten or younger when the bridge was completed obtain an extra year of schooling after the bridge construction, although this is not enough to affect their propensity to enrol in secondary school.

The results for women from better-off families (Tables 9-13) tell a different story. These women are more likely to migrate and reside in Dhaka-by about 5 percentage points-after the construction of the bridge (Table 9). The effect on migration is due to an increase in family-related migration towards Dhaka, with no evidence that economic migration responds to the opening of the bridge (Table 9, Columns 4-8). The estimates in Table 11 provide further insights into the nature of this family-related migration: there is no effect on the respondents' probability of marrying a man born in the Dhaka region, but there is increased probability (3.8 percentage points) of marrying someone who has migrated to Dhaka. We also find that the bridge increased the propensity to marry men from a different district (6.2 percentage points; Table 11). Finally, we 
find a strong effect on marriage-related payments (Table 12), with the opening of the bridge producing a roughly 30 per cent increase in the value of the dowry (in real terms) conditional on a dowry payment during the marriage. ${ }^{18}$

Table 9: Migration outcomes for respondents with parental landholdings of half an acre or more

\begin{tabular}{|c|c|c|c|c|c|c|c|c|}
\hline & $\begin{array}{c}\text { (1) } \\
\text { reside dhaka }\end{array}$ & $\begin{array}{c}(2) \\
\text { reside dhaka }\end{array}$ & $\begin{array}{c}(3) \\
\text { marriage mig }\end{array}$ & $\begin{array}{c}(4) \\
\text { marriage mig }\end{array}$ & $\begin{array}{c}(5) \\
\text { economic mig }\end{array}$ & $\begin{array}{c}(6) \\
\text { economic mig }\end{array}$ & $\begin{array}{c}(7) \\
\text { migr dhaka }\end{array}$ & $\begin{array}{c}(8) \\
\text { migr dhaka }\end{array}$ \\
\hline JM bridge $\mathrm{X}$ post & $\begin{array}{l}0.055^{* *} \\
(0.021)\end{array}$ & & $\begin{array}{l}0.036^{* *} \\
(0.015)\end{array}$ & & $\begin{array}{c}0.014 \\
(0.015)\end{array}$ & & $\begin{array}{l}0.050^{* *} \\
(0.021)\end{array}$ & \\
\hline $\begin{array}{l}\text { JM bridge } \\
\text { (intensity) } \mathrm{X} \text { post }\end{array}$ & & $\begin{array}{c}0.107^{* * *} \\
(0.037)\end{array}$ & & $\begin{array}{c}0.073^{* *} \\
(0.026)\end{array}$ & & $\begin{array}{c}0.026 \\
(0.026)\end{array}$ & & $\begin{array}{c}0.098^{* * *} \\
(0.037)\end{array}$ \\
\hline $\begin{array}{l}\text { JM bridge } \\
\text { (intensity) }\end{array}$ & & $\begin{array}{l}-0.321 \\
(0.341)\end{array}$ & & $\begin{array}{c}-0.665^{* *} \\
(0.233)\end{array}$ & & $\begin{array}{c}0.289 \\
(0.178)\end{array}$ & & $\begin{array}{l}-0.300 \\
(0.277)\end{array}$ \\
\hline born post 1982 & $\begin{array}{c}-0.046^{* *} \\
(0.019)\end{array}$ & $\begin{array}{c}-0.048 * * \\
(0.019)\end{array}$ & $\begin{array}{l}-0.013 \\
(0.013)\end{array}$ & $\begin{array}{l}-0.014 \\
(0.013)\end{array}$ & $\begin{array}{l}-0.026^{* *} \\
(0.011)\end{array}$ & $\begin{array}{c}-0.026^{* *} \\
(0.011)\end{array}$ & $\begin{array}{c}-0.035^{* *} \\
(0.016)\end{array}$ & $\begin{array}{c}-0.037^{* *} \\
(0.016)\end{array}$ \\
\hline dist to RMG (10km) & $\begin{array}{c}-0.012^{\cdots *} \\
(0.002)\end{array}$ & $\begin{array}{c}-0.013 \cdots \\
(0.003)\end{array}$ & $\begin{array}{c}-0.008 * \cdots \\
(0.002)\end{array}$ & $\begin{array}{c}-0.010^{* *} \\
(0.002)\end{array}$ & $\begin{array}{r}-0.002^{*} \\
(0.001)\end{array}$ & $\begin{array}{l}-0.001 \\
(0.001)\end{array}$ & $\begin{array}{c}-0.009 * \cdots \\
(0.002)\end{array}$ & $\begin{array}{c}-0.010^{* * *} \\
(0.002)\end{array}$ \\
\hline river cross & $\begin{array}{c}-0.226^{* * *} \\
(0.044)\end{array}$ & $\begin{array}{c}-0.226^{* *} \\
(0.044)\end{array}$ & $\begin{array}{c}-0.138^{* *} \\
(0.031)\end{array}$ & $\begin{array}{c}-0.138^{* * *} \\
(0.031)\end{array}$ & $\begin{array}{c}-0.032^{*} \\
(0.018)\end{array}$ & $\begin{array}{r}-0.032^{*} \\
(0.018)\end{array}$ & $\begin{array}{c}-0.158^{* *} \\
(0.037)\end{array}$ & $\begin{array}{c}-0.158^{* *} \\
(0.037)\end{array}$ \\
\hline age & $\begin{array}{c}-0.041 \cdots \\
(0.011)\end{array}$ & $\begin{array}{c}-0.041^{\cdots *} \\
(0.011)\end{array}$ & $\begin{array}{l}-0.014^{*} \\
(0.008)\end{array}$ & $\begin{array}{l}-0.014^{*} \\
(0.008)\end{array}$ & $\begin{array}{c}-0.016^{* *} \\
(0.006)\end{array}$ & $\begin{array}{c}-0.016^{* *} \\
(0.006)\end{array}$ & $\begin{array}{c}-0.030^{* *} \\
(0.010)\end{array}$ & $\begin{array}{c}-0.030^{* * *} \\
(0.010)\end{array}$ \\
\hline age sq & $\begin{array}{c}0.001 \cdots \\
(0.000)\end{array}$ & $\begin{array}{l}0.001 \cdots \\
(0.000)\end{array}$ & $\begin{array}{c}0.000 \\
(0.000)\end{array}$ & $\begin{array}{c}0.000 \\
(0.000)\end{array}$ & $\begin{array}{l}0.000^{*} \\
(0.000)\end{array}$ & $\begin{array}{l}0.000^{*} \\
(0.000)\end{array}$ & $\begin{array}{l}0.000^{* *} \\
(0.000)\end{array}$ & $\begin{array}{l}0.000^{* *} \\
(0.000)\end{array}$ \\
\hline Constant & $\begin{array}{c}1.224 \cdots \\
(0.166)\end{array}$ & $\begin{array}{c}1.232 * * \\
(0.166)\end{array}$ & $\begin{array}{c}0.499^{* * *} \\
(0.121)\end{array}$ & $\begin{array}{c}0.515^{* *} \cdot \\
(0.122)\end{array}$ & $\begin{array}{c}0.477^{\cdots \cdots} \\
(0.106)\end{array}$ & $\begin{array}{c}0.470 \cdots \\
(0.107)\end{array}$ & $\begin{array}{c}0.935 \cdots \\
(0.152)\end{array}$ & $\begin{array}{c}0.943 \cdots \\
(0.153)\end{array}$ \\
\hline Observations & 3355 & 3355 & 3355 & 3355 & 3355 & 3355 & 3355 & 3355 \\
\hline
\end{tabular}

Note: Robust standard errors clustered by subdistrict in parentheses.

Source: Authors' construction based on WiLCAS (2014).

${ }^{18}$ All of these estimated effects are sizeable in magnitude relative to the mean values reported in Table 1. 
Table 10: Work outcomes for respondents with parental landholdings of half an acre or more

\begin{tabular}{|c|c|c|}
\hline & $\begin{array}{c}\text { (1) } \\
\text { worked in RMG }\end{array}$ & $\begin{array}{c}\text { (2) } \\
\text { worked in RMG }\end{array}$ \\
\hline JM bridge $\mathrm{X}$ post & $\begin{array}{l}0.047^{* *} \\
(0.023)\end{array}$ & \\
\hline $\begin{array}{l}\text { JM bridge } \\
\text { (intensity) X post }\end{array}$ & & $\begin{array}{l}0.080^{*} \\
(0.041)\end{array}$ \\
\hline $\begin{array}{l}\text { JM bridge } \\
\text { (intensity) }\end{array}$ & & $\begin{array}{c}0.139 \\
(0.295)\end{array}$ \\
\hline born post 1982 & $\begin{array}{l}-0.005 \\
(0.021)\end{array}$ & $\begin{array}{l}-0.005 \\
(0.021)\end{array}$ \\
\hline dist to RMG $(10 \mathrm{~km})$ & $\begin{array}{l}-0.000 \\
(0.002)\end{array}$ & $\begin{array}{c}0.001 \\
(0.002)\end{array}$ \\
\hline river cross & $\begin{array}{c}-0.057^{* *} \\
(0.026)\end{array}$ & $\begin{array}{c}-0.057^{* *} \\
(0.026)\end{array}$ \\
\hline age & $\begin{array}{l}-0.001 \\
(0.012)\end{array}$ & $\begin{array}{l}-0.001 \\
(0.012)\end{array}$ \\
\hline age sq & $\begin{array}{l}-0.000 \\
(0.000)\end{array}$ & $\begin{array}{l}-0.000 \\
(0.000)\end{array}$ \\
\hline Constant & $\begin{array}{c}0.285 \\
(0.180) \\
\end{array}$ & $\begin{array}{r}0.278 \\
(0.180) \\
\end{array}$ \\
\hline Observations & 2119 & 2119 \\
\hline
\end{tabular}

Notes: $p<0.10,{ }^{* *} p<0.05,{ }^{* * *} p<0.01$; robust standard errors clustered by subdistrict in parentheses. Source: Authors' construction based on WiLCAS (2014).

Table 11: Marriage outcomes for respondents with parental landholdings of half an acre or more

\begin{tabular}{|c|c|c|c|c|c|c|}
\hline & $\begin{array}{c}\text { (1) } \\
\text { same district }\end{array}$ & $\begin{array}{c}(2) \\
\text { same district }\end{array}$ & $\begin{array}{c}\text { (3) } \\
\text { husb dhaka }\end{array}$ & $\begin{array}{c}\text { (4) } \\
\text { husb dhaka }\end{array}$ & $\begin{array}{c}\text { (5) } \\
\text { husb mig dhaka }\end{array}$ & $\begin{array}{c}\text { (6) } \\
\text { husb mig dhaka }\end{array}$ \\
\hline JM bridge $\mathrm{X}$ post & $\begin{array}{l}-0.062^{*} \\
(0.033)\end{array}$ & & $\begin{array}{l}-0.003 \\
(0.012)\end{array}$ & & $\begin{array}{c}0.038^{* * *} \\
(0.014)\end{array}$ & \\
\hline $\begin{array}{l}\text { JM bridge } \\
\text { (intensity) X post }\end{array}$ & & $\begin{array}{l}-0.095 \\
(0.059)\end{array}$ & & $\begin{array}{c}0.001 \\
(0.022)\end{array}$ & & $\begin{array}{c}0.067^{*+*} \\
(0.024)\end{array}$ \\
\hline $\begin{array}{l}\text { JM bridge } \\
\text { (intensity) }\end{array}$ & & $\begin{array}{l}-0.460 \\
(0.474)\end{array}$ & & $\begin{array}{c}-0.989^{* * *} \\
(0.254)\end{array}$ & & $\begin{array}{c}0.052 \\
(0.161)\end{array}$ \\
\hline born post 1982 & $\begin{array}{c}0.039 \\
(0.028)\end{array}$ & $\begin{array}{c}0.037 \\
(0.028)\end{array}$ & $\begin{array}{l}-0.021 \\
(0.015)\end{array}$ & $\begin{array}{l}-0.022 \\
(0.015)\end{array}$ & $\begin{array}{l}-0.019^{*} \\
(0.010)\end{array}$ & $\begin{array}{l}-0.019^{*} \\
(0.010)\end{array}$ \\
\hline dist to RMG (10km) & $\begin{array}{l}-0.001 \\
(0.002)\end{array}$ & $\begin{array}{l}-0.003 \\
(0.003)\end{array}$ & $\begin{array}{c}-0.010^{4 * *} \\
(0.002)\end{array}$ & $\begin{array}{c}-0.013^{*+*} \\
(0.003)\end{array}$ & $\begin{array}{l}-0.001 \\
(0.001)\end{array}$ & $\begin{array}{l}-0.001 \\
(0.001)\end{array}$ \\
\hline river cross & $\begin{array}{c}0.023 \\
(0.038)\end{array}$ & $\begin{array}{c}0.023 \\
(0.038)\end{array}$ & $\begin{array}{c}-0.192^{4 * *} \\
(0.042)\end{array}$ & $\begin{array}{c}-0.193^{*+*} \\
(0.041)\end{array}$ & $\begin{array}{c}-0.029^{* * *} \\
(0.011)\end{array}$ & $\begin{array}{c}-0.029^{* * *} \\
(0.011)\end{array}$ \\
\hline age & $\begin{array}{l}0.034^{* *} \\
(0.016)\end{array}$ & $\begin{array}{l}0.034^{* *} \\
(0.016)\end{array}$ & $\begin{array}{c}0.008 \\
(0.007)\end{array}$ & $\begin{array}{c}0.008 \\
(0.007)\end{array}$ & $\begin{array}{c}-0.032^{* * *} \\
(0.008)\end{array}$ & $\begin{array}{c}-0.032^{* *} \\
(0.008)\end{array}$ \\
\hline age sq & $\begin{array}{l}-0.000^{*} \\
(0.000)\end{array}$ & $\begin{array}{l}-0.000^{*} \\
(0.000)\end{array}$ & $\begin{array}{l}-0.000 \\
(0.000)\end{array}$ & $\begin{array}{l}-0.000 \\
(0.000)\end{array}$ & $\begin{array}{c}0.000^{* * *} \\
(0.000)\end{array}$ & $\begin{array}{c}0.000^{* * *} \\
(0.000)\end{array}$ \\
\hline Constant & $\begin{array}{c}0.140 \\
(0.245)\end{array}$ & $\begin{array}{c}0.153 \\
(0.246)\end{array}$ & $\begin{array}{c}0.198^{*} \\
(0.111)\end{array}$ & $\begin{array}{c}0.222^{* *} \\
(0.112)\end{array}$ & $\begin{array}{c}0.651^{* * *} \\
(0.130)\end{array}$ & $\begin{array}{c}0.649^{*+*} \\
(0.130)\end{array}$ \\
\hline Observations & 3181 & 3181 & 3181 & 3181 & 3181 & 3181 \\
\hline
\end{tabular}

Notes: $p<0.10,{ }^{* *} p<0.05,{ }^{* * *} p<0.01$; robust standard errors clustered by subdistrict in parentheses. Source: Authors' construction based on WiLCAS (2014). 
Table 12: Dowry outcomes for respondents with parental landholdings of half an acre or more

\begin{tabular}{|c|c|c|c|c|}
\hline & $\begin{array}{c}(1) \\
\text { dowry }\end{array}$ & $\begin{array}{c}(2) \\
\text { dowry }\end{array}$ & $\begin{array}{c}\text { (3) } \\
\text { In real dowry }\end{array}$ & $\begin{array}{c}(4) \\
\text { ln real dowry }\end{array}$ \\
\hline JM bridge $\mathrm{X}$ post & $\begin{array}{l}-0.037 \\
(0.039)\end{array}$ & & $\begin{array}{l}0.279^{* *} \\
(0.115)\end{array}$ & \\
\hline $\begin{array}{l}\mathrm{JM} \text { bridge } \\
\text { (intensity) X post }\end{array}$ & & $\begin{array}{l}-0.078 \\
(0.069)\end{array}$ & & $\begin{array}{l}0.498^{* *} \\
(0.192)\end{array}$ \\
\hline $\begin{array}{l}\text { JM bridge } \\
\text { (intensity) }\end{array}$ & & $\begin{array}{l}0.788^{* *} \\
(0.400)\end{array}$ & & $\begin{array}{l}-2.365^{*} \\
(1.322)\end{array}$ \\
\hline born post 1982 & $\begin{array}{c}0.004 \\
(0.033)\end{array}$ & $\begin{array}{c}0.005 \\
(0.033)\end{array}$ & $\begin{array}{c}-0.231^{*} \\
(0.122)\end{array}$ & $\begin{array}{l}-0.235^{*} \\
(0.122)\end{array}$ \\
\hline dist to RMG (10km) & $\begin{array}{l}-0.006 * * \\
(0.002)\end{array}$ & $\begin{array}{l}-0.003 \\
(0.003)\end{array}$ & $\begin{array}{c}0.004 \\
(0.008)\end{array}$ & $\begin{array}{l}-0.007 \\
(0.012)\end{array}$ \\
\hline river cross & $\begin{array}{l}-0.006 \\
(0.045)\end{array}$ & $\begin{array}{l}-0.006 \\
(0.045)\end{array}$ & $\begin{array}{l}-0.013 \\
(0.141)\end{array}$ & $\begin{array}{l}-0.016 \\
(0.138)\end{array}$ \\
\hline age & $\begin{array}{l}0.040^{* *} \\
(0.016)\end{array}$ & $\begin{array}{l}0.040^{* *} \\
(0.017)\end{array}$ & $\begin{array}{c}0.039 \\
(0.061)\end{array}$ & $\begin{array}{c}0.040 \\
(0.061)\end{array}$ \\
\hline age sq & $\begin{array}{c}-0.001^{* *} \\
(0.000)\end{array}$ & $\begin{array}{c}-0.001^{* *} \\
(0.000)\end{array}$ & $\begin{array}{c}-0.001 \\
(0.001)\end{array}$ & $\begin{array}{l}-0.001 \\
(0.001)\end{array}$ \\
\hline Constant & $\begin{array}{l}-0.069 \\
(0.241)\end{array}$ & $\begin{array}{l}-0.088 \\
(0.242)\end{array}$ & $\begin{array}{c}10.063^{* * *} \\
(0.919)\end{array}$ & $\begin{array}{c}10.146^{* * *} \\
(0.920)\end{array}$ \\
\hline Observations & 3181 & 3181 & 1212 & 1212 \\
\hline
\end{tabular}

Notes: $p<0.10,{ }^{* *} p<0.05,{ }^{* *} p<0.01$; robust standard errors clustered by subdistrict in parentheses; including only respondents with positive dowry amounts.

Source: Authors' construction based on WiLCAS (2014).

Table 13: Education outcomes for respondents with parental landholdings of half an acre or more

\begin{tabular}{|c|c|c|c|c|c|c|c|c|}
\hline & $\begin{array}{c}(1) \\
\text { yrs educ }\end{array}$ & $\begin{array}{c}(2) \\
\text { yrs educ }\end{array}$ & $\begin{array}{c}(3) \\
\text { yrs educ }\end{array}$ & $\begin{array}{c}(4) \\
\text { yrs educ }\end{array}$ & $\begin{array}{c}(5) \\
\text { sec_school }\end{array}$ & $\begin{array}{c}(6) \\
\text { sec_school }\end{array}$ & $\begin{array}{c}(7) \\
\text { sec_school }\end{array}$ & $\begin{array}{c}(8) \\
\text { sec_school }\end{array}$ \\
\hline JM bridge $\mathrm{X}$ post & $\begin{array}{l}0.770^{* *} \\
(0.309)\end{array}$ & & & & $\begin{array}{l}0.064^{*} \\
(0.038)\end{array}$ & & & \\
\hline $\begin{array}{l}\mathrm{JM} \text { bridge } \\
\text { (intensity) } \mathrm{X} \text { post }\end{array}$ & & $\begin{array}{l}1.306^{* *} \\
(0.544)\end{array}$ & & & & $\begin{array}{l}0.111^{*} \\
(0.066)\end{array}$ & & \\
\hline $\begin{array}{l}\text { JM bridge } \mathrm{X} \text { post } \\
\text { (10 yrs) }\end{array}$ & & & $\begin{array}{c}1.050^{\cdots *} \\
(0.271)\end{array}$ & & & & $\begin{array}{c}0.140^{\cdots} \cdots \\
(0.036)\end{array}$ & \\
\hline $\begin{array}{l}\text { JM bridge } \\
\text { (intensity) } \mathrm{X} \text { post ( } 10 \mathrm{yrs})\end{array}$ & & & & $\begin{array}{c}1.856^{* *} \\
(0.472)\end{array}$ & & & & $\begin{array}{c}0.246^{\cdots} \\
(0.061)\end{array}$ \\
\hline $\begin{array}{l}\text { JM bridge } \\
\text { (intensity) }\end{array}$ & & $\begin{array}{c}-12.233^{* *} \\
(2.886)\end{array}$ & & $\begin{array}{c}-11.843^{* *} \\
(2.998)\end{array}$ & & $\begin{array}{c}-1.388^{* *} \\
(0.396)\end{array}$ & & $\begin{array}{c}-1.396^{* *} \\
(0.415)\end{array}$ \\
\hline born post 1982 & $\begin{array}{c}0.034 \\
(0.266)\end{array}$ & $\begin{array}{c}0.044 \\
(0.265)\end{array}$ & & & $\begin{array}{c}0.050 \\
(0.036)\end{array}$ & $\begin{array}{c}0.051 \\
(0.036)\end{array}$ & & \\
\hline born post 1987 & & & $\begin{array}{c}-0.587^{* *} \\
(0.252)\end{array}$ & $\begin{array}{c}-0.599^{* *} \\
(0.252)\end{array}$ & & & $\begin{array}{c}-0.074^{* *} \\
(0.037)\end{array}$ & $\begin{array}{l}-0.076^{* *} \\
(0.037)\end{array}$ \\
\hline dist to RMG (10km) & $\begin{array}{l}-0.009 \\
(0.018)\end{array}$ & $\begin{aligned}-0.048^{* *} \\
(0.019)\end{aligned}$ & $\begin{array}{l}-0.010 \\
(0.018)\end{array}$ & $\begin{array}{l}-0.048^{* *} \\
(0.020)\end{array}$ & $\begin{array}{c}0.000 \\
(0.002)\end{array}$ & $\begin{array}{l}-0.004 \\
(0.003)\end{array}$ & $\begin{array}{c}0.000 \\
(0.002)\end{array}$ & $\begin{array}{r}-0.004 \\
(0.003)\end{array}$ \\
\hline river cross & $\begin{array}{c}0.693^{* *} \\
(0.212)\end{array}$ & $\begin{array}{r}0.689^{* * *} \\
(0.210)\end{array}$ & $\begin{array}{c}0.685^{* *} \\
(0.214)\end{array}$ & $\begin{array}{c}0.681^{\cdots *} \\
(0.213)\end{array}$ & $\begin{array}{l}0.089^{* *} \\
(0.036)\end{array}$ & $\begin{array}{l}0.089^{* *} \\
(0.036)\end{array}$ & $\begin{array}{l}0.089^{* *} \\
(0.036)\end{array}$ & $\begin{array}{l}0.088^{* *} \\
(0.036)\end{array}$ \\
\hline age & $\begin{array}{c}-0.272^{* *} \\
(0.112)\end{array}$ & $\begin{array}{c}-0.270^{* *} \\
(0.112)\end{array}$ & $\begin{array}{c}-0.358^{* \cdots} \\
(0.132)\end{array}$ & $\begin{array}{c}-0.358^{\cdots} \cdots \\
(0.131)\end{array}$ & $\begin{array}{l}-0.019 \\
(0.015)\end{array}$ & $\begin{array}{l}-0.019 \\
(0.015)\end{array}$ & $\begin{array}{c}-0.025 \\
(0.019)\end{array}$ & $\begin{array}{c}-0.025 \\
(0.019)\end{array}$ \\
\hline age sq & $\begin{array}{c}0.001 \\
(0.002)\end{array}$ & $\begin{array}{c}0.001 \\
(0.002)\end{array}$ & $\begin{array}{c}0.002 \\
(0.002)\end{array}$ & $\begin{array}{c}0.002 \\
(0.002)\end{array}$ & $\begin{array}{l}-0.000 \\
(0.000)\end{array}$ & $\begin{array}{l}-0.000 \\
(0.000)\end{array}$ & $\begin{array}{c}-0.000 \\
(0.000)\end{array}$ & $\begin{array}{c}-0.000 \\
(0.000)\end{array}$ \\
\hline Constant & $\begin{array}{c}10.392^{* * *} \\
(1.606)\end{array}$ & $\begin{array}{c}10.666^{* * *} \\
(1.599) \\
\end{array}$ & $\begin{array}{c}12.433 \cdots * \\
(2.125)\end{array}$ & $\begin{array}{c}12.754^{* *} \\
(2.112) \\
\end{array}$ & $\begin{array}{c}0.850^{* * *} \\
(0.218)\end{array}$ & $\begin{array}{c}0.882^{* * *} \\
(0.218)\end{array}$ & $\begin{array}{c}1.093^{* * *} \\
(0.315)\end{array}$ & $\begin{array}{c}1.131^{\cdots} \cdots \\
(0.314)\end{array}$ \\
\hline Observations & 3355 & 3355 & 3355 & 3355 & 3355 & 3355 & 3355 & 3355 \\
\hline
\end{tabular}

Notes: $\mathrm{p}<0.10,{ }^{* *} \mathrm{p}<0.05,{ }^{* * *} \mathrm{p}<0.01$; robust standard errors clustered by subdistrict in parentheses.

Source: Authors' construction based on WiLCAS (2014). 
Although we find no effect of the bridge on economic migration, the women from better-off families are, in fact, more likely-by 4.7 percentage points - to have ever worked in the readymade garments sector (Table 10). For comparison, the presence of a river between the individual's place of birth and the Dhaka region reduces her probability of having worked in the RMG sector by 5.7 percentage points (Table 10). Last, we see that the women from the better-off familieslike the women from the poorer families - in the north-western divisions of Bangladesh also obtain an extra year of schooling after the bridge was completed, and in their case this increase in the intensive margin of educational attainment is coupled with an increased propensity (by 14 percentage points) to enrol in secondary school (Table 13).

The estimates obtained with the treatment intensity variable (JM bridge (intensity) $\times$ post) are in line with those obtained with the binary treatment indicator. But the former estimates also give a measure of the variation of the effects of the bridge for women born in different parts of northwestern Bangladesh. For example, the estimated coefficient of 0.098 in Table 9, Column 8, implies that effect of the bridge on the probability of migrating to Dhaka varies between 4.36 $(=0.098 \times 0.445)$ and 7.2 percentage points $(=0.098 \times 0.736)$ for women born in villages (in north-western Bangladesh) exposed, respectively, to the lowest and highest levels of treatment intensity. Similarly, the probability of having worked in the RMG sector varies between 3.56 and 5.89 percentage points and the probability of marriage with a groom who migrates to Dhaka varies between 2.98 and 4.93 percentage points.

The results for both sets of women are indicative of our working hypotheses and consistent with the theoretical framework sketched in Section 4. First, the results are consistent with the hypothesis that social norms prevent women, of all backgrounds, from migrating by themselves to take advantage of the greater work opportunities in the Dhaka area, as there is no indication of greater migration for economic reasons. There is evidence of migration to Dhaka-but only through marriage, and only for those wealthy enough to compete for migrating men on the marriage market by paying the higher dowries that these men can now demand. The fact that women cannot migrate except by marrying a male migrant - and that even this opportunity is not available to the least well off-is evidence of significant and uneven labour market frictions, with considerable implications for efficiency as well as equity.

\section{$7 \quad$ Discussion}

In this paper we use the construction of a major bridge in Bangladesh to shed light on the marriage, work, and migration behaviour of women in developing countries. Using a difference-indifferences strategy that exploits the location of households and the year in which women made their coupled marriage/migration decisions, we find that the significant reduction in the cost of migration caused by the bridge construction had no effect on direct female economic migration towards Dhaka (the largest urban centre). However, it did lead to an increase in marriage-related urban migration for women from richer families, as they were able to bid for and match with men who migrated to Dhaka, by paying higher dowries. Once in Dhaka, these richer women were able to work in the ready-made garments sector. While most of these effects were only experienced by women from wealthier families, all groups of women experienced higher educational attainment in response to the bridge construction, suggesting that it played a role in increasing the returns to education.

There are two main implications that follow from the results summarized above. First, social norms that prevent women from responding to economic opportunities appear to constitute a significant friction in the labour market that is likely to increase firm costs and reduce output. 
Second, if migration is restricted to those women who can outbid others on the marriage market, the gains that are realized through migration (for women) are unequally distributed - to those from richer families. Thus, our findings suggest that the current informal institutions that govern female mobility and marriage matching patterns in Bangladesh may adversely affect efficiency as well as equity.

The implications of this work for policy are important but somewhat negative: building infrastructure may be effective in reducing wedges between marginal products in rural and urban areas. However, it is likely to be even more effective if governments can make progress on the more difficult task of changing gender norms.

\section{References}

Adukia, A., S. Asher, and P. Novosad (2017). 'Educational Investment Responses to Economic Opportunity: Evidence from Indian Road Construction'. Working Paper 2017-08. Chicago: Becker Friedman Institute for Research in Economics. http://dx.doi.org/10.2139/ ssrn.2967464.

Ahmad, I., P.E., S. Azhar, and S.M. Ahmed (2003). 'Construction of a Bridge in a Developing Country: A Bangladesh Case Study'. Leadership and Management in Engineering, 3(4): 17782. https://doi.org/10.1061/(ASCE)1532-6748(2003)3:4(177).

Anderson, S., and M. Eswaran (2009). 'What Determines Female Autonomy? Evidence from Bangladesh'. Journal of Development Economics, 90(2): 179-91. https://doi.org/10.1016/ j.jdeveco.2008.10.004.

Asadullah, M.N., and N. Chaudhury (2009). 'Reverse Gender Gap in Schooling in Bangladesh: Insights from Urban and Rural Households'. Journal of Development Studies, 45(8): 1360_ 80. https://doi.org/10.1080/00220380902935824.

Asadullah, M.N., and Z. Wahhaj (2017). 'Missing from the Market: Purdah Norm and Women's Paid Work Participation in Bangladesh'. GLO Discussion Paper 21. Maastricht: Global Labor Organization (GLO).

Asher, S., and P. Novosad (2016). 'Market Access and Structural Transformation: Evidence from Rural Roads in India'. Working paper.

Banerjee, A., E. Duflo, and N. Qian (2012). 'On the Road: Access to Transportation Infrastructure and Economic Growth in China'. NBER Working Paper 17897. Cambridge, MA: National Bureau of Economic Research (NBER).

Bird, J., and S. Straub (2014). 'The Brasília Experiment: Road Access and the Spatial Pattern of Long-Term Local Development in Brazil'. Policy Research Working Paper 6964. Washington, DC: World Bank.

Blankespoor, B., M.S. Emran, F. Shilpi, and L. Xu (2018). 'Bridge to Bigpush or Backwash? Market Integration, Reallocation, and Productivity Effects of Jamuna Bridge in Bangladesh'. MPRA Paper 86199. Munich: Munich Personal RePEc Archive.

Bryan, G., S. Chowdhury, and A.M. Mobarak (2014). 'Underinvestment in a Profitable Technology: The Case of Seasonal Migration in Bangladesh'. Econometrica, 82(5): 1671-748. https://doi.org/10.3982/ECTA10489. 
Donaldson, D. (2018). 'Railroads of the Raj: Estimating the Impact of Transportation Infrastructure'. American Economic Review, 108(4-5): 899-934. DOI: $10.1257 /$ aer.20101199.

Donaldson, D., and R. Hornbeck (2016). 'Railroads and American Economic Growth: a "Market access” Approach'. Quarterly Journal of Economics, 131(2): 799-858. https://doi.org/10.1093/ qje/ qjw002.

Harris, J.R., and M.P. Todaro (1970). 'Migration, Unemployment and Development: A Two-Sector Analysis'. American Economic Review, 60(1): 126-42.

Heath, R., and A. Mushfiq Mobarak (2015). 'Manufacturing Growth and the Lives of Bangladeshi Women'. Journal of Development Economics, 115: 1-15. DOI: 10.1016/j.jdeveco.2015.01.006.

Heintz, J., N. Kabeer, and S. Mahmud (2018). 'Cultural Norms, Economic Incentives and Women's Labour Market Behaviour: Empirical Insights from Bangladesh'. Oxford Development Studies, 46(2): 266-89. https:/ / doi.org/10.1080/13600818.2017.1382464.

Joshi, S., and T.P. Schultz (2007). 'Family Planning as an Investment in Development: Evaluation of a Program's Consequences in Matlab, Bangladesh'. Economic Growth Center Discussion Paper 951. New Haven, CT: Yale University.

Khandker, S., and G. Koolwal (2011). 'Estimating the Long-Term Impacts of Rural Roads: A Dynamic Panel Approach'. Policy Research Working Paper 5867. Washington, DC: World Bank.

Khandker, S., Z. Bakht, and G. Koolwal (2009). 'The Poverty Impact of Rural Roads: Evidence from Bangladesh'. Economic Development and Cultural Change, 57(4): 685-722. DOI: $10.1086 / 598765$.

Khatun, F., M. Rahman, D. Bhattacharya, and K.G. Moazzem (2008). Gender and Trade Liberalisation in Bangladesh: The Case of the Readymade Garments. Dhaka: Centre for Policy Dialogue.

Lewis, A.W. (1954). 'Economic Development with Unlimited Supplies of Labour'. The Manchester School, 22(2): 139-91. https:// doi.org/10.1111/j.1467-9957.1954.tb00021.x.

Lundberg, S., and R.A. Pollak (1993). 'Separate Spheres: Bargaining and the Marriage Market'. Journal of Political Economy, 101(6): 988-1010.

Mahmud, M., and Y. Sawada (2015). 'Infrastructure and Well-Being: Employment Effects of Jamuna Bridge in Bangladesh'. Journal of Development Effectiveness, 10(3): 327-40. https://doi.org/10.1080/19439342.2018.1483415.

Mahmud, S., and S. Tasneem (2011). 'The Under-Reporting of Women's Economic Activity in Bangladesh: An Examination of Official Statistics'. BDI Working Paper 01. Dhaka: Brac Development Institute (BDI).

Meng, X., and J. Ryan (2010). 'Does a Food for Education Program Affect School Outcomes? The Bangladesh Case'. Journal of Population Economics, 23(2): 415-47. DOI 10.1007/s00148-009-0240-0.

Morten, M., and J. Oliveira (2014). 'Migration, Roads and Labor Market Integration: Evidence from a Planned Capital City'. Working Paper.

NIPORT, Mitra and Associates, and ICF International (2013). Bangladesh Demographic and Health Survey, 2011. Dhaka/Calverton, MD: NIPORT (National Institute of Population Research and Training), Mitra and Associates, and ICF International. 
Pitt, M.M., and S.R. Khandker (1998). 'The Impact of Group-Based Credit Programs on Poor Households in Bangladesh: Does the Gender of Participants Matter?' Journal of Political Economy, 106(5): 958-96.

Rahman, R.I., and R. Islam (2013). 'Female Labour Force Participation in Bangladesh: Trends, Drivers and Barriers'. ILO Working Paper 994834893402676. Geneva: International Labour Organization (ILO).

Rosenzweig, M.R., and O. Stark (1989). 'Consumption Smoothing, Migration, and Marriage: Evidence from Rural India'. Journal of Political Economy, 97(4): 905-26.

Schurmann, A.T. (2009). 'Review of the Bangladesh Female Secondary School Stipend Project Using a Social Exclusion Framework'. Journal of Health Population and Nutrition, 27(4): 505-17. 